\title{
PAleoearthQuaKes in The PribaikAlie: MethodS AND RESULTS OF DATING
}

\author{
O. P. Smekalin, A. V. Chipizubov, V. S. Imayev \\ Institute of the Earth's crust SB RAS, 664033, Irkutsk, Lermontov str., 128, Russia
}

\begin{abstract}
In the Pribaikalie and adjacent territories, seismogeological studies have been underway for almost a half of the century and resulted in discovery of more than 70 dislocations of seismic or presumably seismic origin. With commencement of paleoseismic studies, dating of paleo-earthquakes was focused on as an indicator useful for long-term prediction of strong earthquakes. V.P. Solonenko [Solonenko, 1977] distinguished five methods for dating paleoseismogenic deformations, i.e. geological, engineering geological, historico-archeological, dendrochronological and radiocarbon methods. However, ages of the majority of seismic deformations, which were subject to studies at the initial stage of development of seismogeology in Siberia, were defined by methods of relative or correlation age determination.

Since the 1980s, studies of seismogenic deformation in the Pribaikalie have been widely conducted with trenching. Mass sampling, followed with radiocarbon analyses and definition of absolute ages of paleo-earthquakes, provided new data on seismic regimes of the territory and rates of and recent displacements along active faults, and enhanced validity of methods of relative dating, in particular morphometry. Capacities of the morphometry method has significantly increased with introduction of laser techniques in surveys and digital processing of 3D relief models.

Comprehensive seismogeological studies conducted in the Pribaikalie revealed 43 paleo-events within 16 seismogenic structures. Absolute ages of 18 paleo-events were defined by the radiocarbon age determination method. Judging by their ages, a number of dislocations were related with historical earthquakes which occurred in the 18th and $19^{\text {th }}$ centuries, yet any reliable data on epicenters of such events are not available. The absolute and relative dating methods allowed us to identify sections in some paleoseismogenic structures by differences in ages of activation and thus provided new data for more accurate definitions of epicenters and magnitudes of the paleo-earthquakes. In some cases, it was revealed that neighboring dislocations of seismogenic structures, which were previously considered independent, had been subject to simultaneous opening.

The article presents a new approach to selecting regression equations to estimate paleo-magnitudes with regard to specific geodynamic conditions as well as to levels of available knowledge on seismodislocations and reliability of available data parameters.
\end{abstract}

Keywords: paleoseismology, paleoseismicity, paleoearthquake, morphometry, trenching.

Recommended by E.A. Rogozhin 15 October 2009

Smekalin O.P., Chipizubov A.V., Imayev V.S. Paleoearthquakes in the Pribaikalie: methods and results of dating // Geodynamics \& Tectonophysics. 2010. V. 1. № 1. P. 55-74.

\section{ПАЛЕОЗЕМЛЕТРЯСЕНИЯ ПРИБАЙКАЛЬЯ: МЕТОДЫ И РЕЗУЛЬТАТЫ ДАТИРОВАНИЯ}

\author{
О. П. Смекалин, А. В. Чипизубов, В. С. Имаев \\ Институт земной коры СО РАН, 664033, Иркутск, ул. Лермонтова, 128, Россия
}

Аннотация: За полувековую историю сейсмогеологических исследований в Прибайкалье и сопредельных территориях в зонах активных разломов выявлены более 70 дислокаций сейсмического или предположительно 
сейсмического происхождения. С начала палеосейсмических исследований определению возраста палеоземлетрясений уделялось особое внимание как одному из признаков долгосрочного прогноза сильных землетрясений. В.П. Солоненко [Солоненко, 1977] выделял пять методов датирования палеосейсмогенных деформаций: геологический, инженерно-геологический, историко-археологический, дендрохронологический и радиоуглеродный. Однако возраст большинства сейсмодеформаций, изучаемых на начальном этапе развития сейсмогеологии в Сибири, был получен с использованием методов относительного или корреляционного датирования.

С конца 80-х годов XX столетия в Прибайкалье для изучения сейсмогенных деформаций стал широко применяться тренчинг - метод изучения сейсмодеформаций в разрезах канав. Массовый отбор проб на радиоуглеродный анализ и получение абсолютных возрастов палеоземлетрясений позволили не только получить данные о сейсмическом режиме территории, современных скоростях перемещений по активным разломам, но и повысить значимость методов относительного датирования, и прежде всего морфометрического. Сами возможности морфометрического метода значительно возросли с внедрением лазерных технологий съёмки местности с последующей цифровой обработкой трёхмерных моделей рельефа.

Комплексные сейсмогеологические исследования, проводимые в Прибайкалье, позволили установить 43 палеособытия в пределах 16 сейсмогенных структур, в том числе для 18 палеособытий установлен абсолютный возраст по результатам радиоуглеродного датирования. В результате определения возраста было установлено, что ряд дислокаций был связан с историческими землетрясениями XVIII и XIX веков, достоверных сведений об эпицентрах которых не существует. Благодаря методам абсолютного и относительного датирования некоторые палеосейсмогенные структуры были дефрагментированы на отрезки с различным временем активации, что позволило уточнить эпицентры и магнитуды палеоземлетрясений. Отмечены случаи единовременного вскрытия дислокаций сейсмогенных структур, расположенных рядом, но считавшихся самостоятельными.

В статье предложен новый подход к выбору уравнений регрессий определения палеомагнитуд в зависимости не только от конкретных геодинамических обстановок, но и от степени изученности сейсмодислокаций и достоверности имеющихся данных об их параметрах.

Ключевые слова: палеосейсмология, палеосейсмичность, палеоземлетрясение, морфометрия, тренчиинг.

\section{ВведенИЕ}

Определение возраста доисторических землетрясений является одной из приоритетных задач палеосейсмологии [Солоненко, 1977; Paleoseismology, 1996; Yeats et al., 1997]. В настоящее время для датирования сильных землетрясений прошлого возможно применение около 25 видов данных: от сведений из исторических летописей до содержащихся в осадках изотопных материалов. В классифрикации методов четвертичного датирования применительно к палеосейсмологии, предложенной С. Колманом и впоследствии модифицированной Дж. Мак-Калпином [Colman et al., 1987; Paleoseismology, 1996], все виды анализа возраста разделены на шесть типов (табл. 1). Получаемый в результате применения того или иного метода возраст может быть представлен одним или несколькими из четырёх типов. Теоретические основы применения методов датирования в палеосейсмологической практике и результаты их использования широко известны по работам таких ученых, как D.J. Andrews, T.C. Hanks, R.C. Bucknam, R.E. Anderson, G.A. Carver, K.R. Lajoie, R.E. Wallace, J.P. McCalpin и др.

Не все из приведённых в табл. 1 методов в равной степени используются с целью датирования сейсмодислокаций или палеоземлетрясений. Ниже в историческом аспекте приведён обзор основных из используемых в Прибайкалье методов датирования и представлены результаты по определению абсолютного возраста палеоземлетрясений Южного Прибайкалья.

В первые десятилетия использования палеосейсмогеологического метода [Солоненко, 1962; Флоренсов, 1960] возраст палеоземлетрясения тесно увязывался с возрастом сформированной им палеосейсмогенной структуры или временем её по- следнего обновления, если речь шла о многоактной структуре. В.П. Солоненко [Солоненко, 1977] выделял пять методов датирования палеосейсмогенных деформаций: геологический, инженерно-геологический, историко-археологический, дендрохронологический и радиоуглеродный. До конца 80-х годов XX столетия в Прибайкалье для изучения сейсмогенных деформаций не применялись работы, связанные с их вскрытием. Это вносило определённые ограничения в использование целого ряда методов датирования дефрормаций. Основным источником данных, используемых с целью оценки возраста, была морфология деформаций, их пространственно-генетическое соотношение со структурами иного генезиса и связь с геолого-тектоническим строением, геодинамическими и географо-климатическими особенностями территории. Получаемые оценки возраста соответствовали относительному или корреляционному типу.

\section{МЕТОДЫ ПОЛУЧЕНИЯ ОТНОСИТЕЛЬНОГО И КОРРЕЛЯЦИОННОГО ВОЗРАСТА}

В отечественных публикациях 60-70-х годов прошлого столетия возраст сейсмогенных дислокаций оценивался по степени их сохранности. В основе исходного материала использовались результаты полевых наземных исследований, аэровизуального наблюдения и дешифрирования космо- и аэроснимков. В некоторых случаях для расчётов использовались значения скоростей денудации, определяемые экспериментально для современных климатических условий. Никакой речи не шло о калибровке значений возраста в зависимости от изменения тех же климатических условий. Приближённые значения возраста, даже в приводимых диапазонах в сотни лет, часто оказывались неверными для тех 
Т а б л и ц а 1. Классификация методов возрастного датирования, применяемых в палеосейсмологии по Дж. МакКэлпину [Paleoseismology, 1996]

$\mathrm{T}$ a b I e 1. Classification of dating methods in paleoseismology, according to J. McCalpin [Paleoseismology, 1996].

\begin{tabular}{|c|c|c|c|c|c|}
\hline \multirow[t]{2}{*}{ Типы методов } & \multirow[t]{2}{*}{ Методы } & \multicolumn{4}{|c|}{ Типы результатов } \\
\hline & & $\begin{array}{l}\text { Абсолютный } \\
\text { возраст }\end{array}$ & $\begin{array}{l}\text { Калиброван- } \\
\text { ный возраст }\end{array}$ & $\begin{array}{l}\text { Относитель- } \\
\text { ный возраст }\end{array}$ & $\begin{array}{l}\text { Корреляцион- } \\
\text { ный возраст }\end{array}$ \\
\hline \multirow[t]{3}{*}{ Календарный } & Исторические сводки & $\Delta$ & - & - & - \\
\hline & Дендрохронологический & $\boldsymbol{\Delta}$ & - & - & - \\
\hline & Сезонно-слоистый & घ & - & - & - \\
\hline \multirow[t]{3}{*}{ Изотопный } & Радиоуглеродный $\left({ }^{14} \mathrm{C}\right)$ & $\Delta$ & ० & - & - \\
\hline & $\mathrm{K}-\mathrm{Ar}$ и ${ }^{39} \mathrm{Ar}-{ }^{40} \mathrm{Ar}$ & घ & $\circ$ & - & - \\
\hline & Космогенные изотопы ${ }^{210} \mathrm{~Pb},{ }^{36} \mathrm{Cl}$ и др. & घ & $\circ$ & - & - \\
\hline \multirow[t]{2}{*}{ Радиоактивный } & Люминесцентный & $\Delta$ & $\boldsymbol{\Delta}$ & ○ & - \\
\hline & Электронно-резонансный & घ & - & o & - \\
\hline \multirow[t]{5}{*}{ Химико-биологический } & Аминокислотный & $\circ$ & घ & घ & $\circ$ \\
\hline & Обсидиан и тефра-гидратный & $\circ$ & घ & घ & $\circ$ \\
\hline & Лихенометрический & $\circ$ & $\boldsymbol{\Delta}$ & $\boldsymbol{\Delta}$ & $\circ$ \\
\hline & Почвенно-химический & $\circ$ & घ & घ & $\circ$ \\
\hline & Химический & ○ & घ & घ & ० \\
\hline \multirow{4}{*}{ Геоморфологический } & Выветривание пород и минералов & - & $\circ$ & घ & घ \\
\hline & Морфометрия & - & ○ & $\boldsymbol{\Delta}$ & $\boldsymbol{\Delta}$ \\
\hline & Скорость осадконакопления & - & $\circ$ & - & घ \\
\hline & Соотношение геоморфологических элементов & - & $\circ$ & $\Delta$ & $\Delta$ \\
\hline \multirow[t]{6}{*}{ Корреляционный } & Литостратиграфический & - & - & $\overline{0}$ & $\boldsymbol{\Delta}$ \\
\hline & Тефрохронологический & - & - & $\circ$ & $\boldsymbol{\Delta}$ \\
\hline & Палеомагнитный & - & - & $\circ$ & घ \\
\hline & Палеонтологический & - & - & ○ & $\Delta$ \\
\hline & Археологический & - & - & ○ & $\boldsymbol{\Delta}$ \\
\hline & Стабильные изотопы & - & - & o & . \\
\hline
\end{tabular}

П р и м е ч а н и е. $\boldsymbol{\Delta}$ - адаптированные к датированию палеоземлетрясений в голоцене и наиболее часто используемые методы, - наиболее подходящие методы для получения соответствующего результата, о - менее подходящие методы.

$\mathrm{N}$ o t e. $\boldsymbol{\Delta}$ - methods adapted to dating of paleoearthquakes in the Holocen and most common methods; $\mathbf{m}-$ most suitable methods; $\circ-$ less suitable methods.

структур, для которых впоследствии было проведено определение абсолютного возраста. Это является закономерным следствием невозможности сколько-нибудь точного определения возраста, если за точку отсчёта берутся динамически развивающиеся формы рельефа или такие фрормы, развитие которых прекратилось задолго до их деформирования в результате сейсмической подвижки. И хотя полученные подобным образом временные оценки нельзя использовать в сейсмопрогностических целях, они необходимы для определения уровня современной сейсмической активности неотектонических структур. С помощью данных об относительном возрасте, определённом для большинства сейсмодислокаций, открытых в 60-70-х годах, в Байкальской рифтовой зоне установлено четыре вспышки сейсмической активности [Солоненко, 1977]. Определение возраста по степени сохранности или молодости структуры следует относить к геоморфологическому типу методов, а получаемый возраст - к корреляционному.

Среди морфологических методов датирования наиболее широкое развитие получила морфометрия (Progressive landform modification). Благодаря своей универсальности, доступности и простоте, этот метод стал одним из основных в палеосейсмологических исследованиях. Различные модификации данного метода, кроме получения относительного и корреляционного возраста, решают и многие другие задачи, стоящие перед палеосейсмологией. Среди последних можно назвать: определение суммарных и разовых амплитуд смещения; выделение на протяжении всего комплекса сейсмодислокации участков (отрезков её длины), характеризующихся одновременным вскрытием; установление самого фракта импульсности подвижки и определение её кинематики и некоторые другие, более частные, задачи, например выделение этапов активизации роста уступа в случае вспарывания разрыва при нескольких разновозрастных подвижках не строго по одной линии [Чипизубов, 1982; Чипизубов и др., 2000].

Для районов с преимущественным развитием рыхлых аллювиальных и эоловых отложений, часто не содержащих органического материала, который может быть датирован, морфометрия зачастую остаётся единственным способом получения приблизительной оценки возраста тектонических уступов.

В основе морфометрического метода оценки возраста дислокации лежат представления об изменении во времени первоначального облика сформировавшихся при землетрясении отдельных элементов рельефа. С помощью детальных исследований для похожих структурных элементов (уступов, рвов и пр.) с известным временем их возникновения определяются эмпирические параметры скорости изменения крутизны уступов, степени заполнения трещин раскрытия, заполнения осадками 
подпруженных котловин и т.д., которые могут быть применены в сходных геолого-географических условиях для палеосейсмогенных структур.

За рубежом морфологические методы датирования сейсмодислокаций начали активно развиваться с началом палеосейсмологических исследований. В 1960-1961 годах Н. Каллинг и А. Шайдеггер первыми опубликовали материалы по аналитическим моделям эрозии применительно к склонам уступов в целом. Морфологические методы количественной оценки возраста сбросовых уступов были описаны многими исследователями [Bucknam, Anderson, 1979; Colman, Watson, 1983; Machette, 1982; Mayer, 1984; Nash, 1980; u dp.].

Р. Букнем и Р. Андерсон описали метод датирования для получения относительного возраста, основанный на сравнении разновозрастных уступов. Они вывели статистическое соотношение между логарифмом высоты уступа и максимальным наклоном уступа. Ими было установлено, что линия регрессии, связывающая максимальный уклон уступа и логарифм его высоты, будет ниже для более древнего уступа, чем для более молодого. Расчёты, сделанные Р. Букнемом и Р. Андерсоном, подтверждают тот фракт, что при одинаковой высоте уступов наиболее молодым из них будет тот, чья поверхность круче.

Д. Нэшем [Nash, 1980] предложена диффрузионная модель деградации сбросовых уступов. Метод датирования сбросовых уступов, основанный на уравнении диффузии, является одним из наиболее простых и доступных методов получения численных значений возраста дислокации. Основные погрешности датирования этим методом (как и другими морфологическими методами) связаны с ошибками измерений, различием в литологии и возможной неоднократной повторяемостью разрывообразования.

Кроме дифффузионного, в аналитической морфометрии нашёл применение метод, использующий линейный дискриминантный анализ. Этот метод датирования уступов основан на морфологических различиях между уступами разного возраста, то есть рассматривается случай, когда возраст является единственным отличием между двумя уступами и морфологические различия обусловлены только возрастом. И хотя это допущение вряд ли может быть выполнимо с практической стороны, метод линейной дискриминантной функции, как и метод, использующий диффузионную модель, может быть применен для выявления факторов, не связанных с возрастом изменений морфологии уступа [Mayer, 1984].

Теоретические основы морфологических методов и полученные практические результаты отражены в большом числе публикаций [Andrews, Hanks, 1985; Hanks, Andrews, 1989; Nash, 1980; u дp.]. В частности, для провинции Бассейнов и Хребтов установлено, что у одновозрастных уступов угол наклона пропорционален логарифму высоты уступа и угол наклона для уступов данной высоты с возрастом уменьшается [Bucknam, Anderson, 1979]. Хотя по причинам, изложенным выше, использова- ние конкретных фрормул уравнений дифффузии и корреляционных зависимостей невозможно для уступов различных географических областей, в то же время выведенные Р. Букнемом и Р. Андерсоном принципы могут быть применимы для любых тектонических уступов. На этих принципах также основан один из приёмов определения участков уступа, обновлённых при разновозрастных подвижках. Здесь в основе концепции лежит представление о том, что более древние, обычно верхние, части уступов будут более выположенными, тогда как последняя подвижка будет выражена более крутым участком у основания или в его середине. На возможность выделения количества палеособытий по заметным перегибам (bevels crest) в поперечных профилях сейсмогенных уступов указывалось более двадцати лет назад [Vittori et al., 1991; Wallace, 1977]. Для сегментации палеосейсмогенных дислокаций на приблизительно одновозрастные отрезки достаточно и относительного возраста. Уступы равной высоты и с одинаковыми углами откосов, сформировавшиеся в отложениях одного типа, должны быть одновозрастными. В последние годы анализ морфологии сейсмогенных уступов для выделения количества палеособытий стал широко применяться в практических целях [Deng, Liao, 1996; Sanders, Slemmons, 1996].

Важную роль в развитии уступов играет состав дислоцированных пород и климат. Только при сходных характеристиках этих параметров различие их воздействия на изменение морфологии от одной точки уступа к другой будет минимальным, а оценка зависимости формы уступа от его возраста будет оправдана для целей сегментации уступа. Меньшее значение в этом плане имеет величина начального наклона уступа, так называемой свободной поверхности уступа, обычно составляющая 50-90. Как правило, в рыхлых отложениях уступ быстро достигает угла естественного откоса (около $35^{\circ}$ ), после чего его выполаживание замедляется. По мнению P. Уоллеса [Wallace, 1977], для уничтожения свободной поверхности уступа в слабосцементированном материале требуется несколько сотен лет и, возможно, тысячи лет в хорошо уплотненном. Нами установлено, что в делювиально-пролювиальных покровах предгорий Прибайкалья свободная поверхность денудируется менее чем за одну тысячу лет. На скорость выполаживания уступа также оказывает влияние изначальная морфология дислоцированной поверхности.

Определение возраста уступов морфометрическим методом вкратце сводится к следующему. Вначале определяется относительный возраст уступа по наличию или отсутствию свободной поверхности, по возрасту датированных форм рельефа и погребённых геологических тел, дислоцированных уступом и перекрывающих его. Далее проводится статистический анализ с целью выявления коррелятивных связей параметров уступа (высота, наклон) и его возраста. При сходстве геолого-климатических условий полученные корреляционные уравнения применяются для определения возраста уступа. Ясно, что такой метод даёт лишь прибли- 

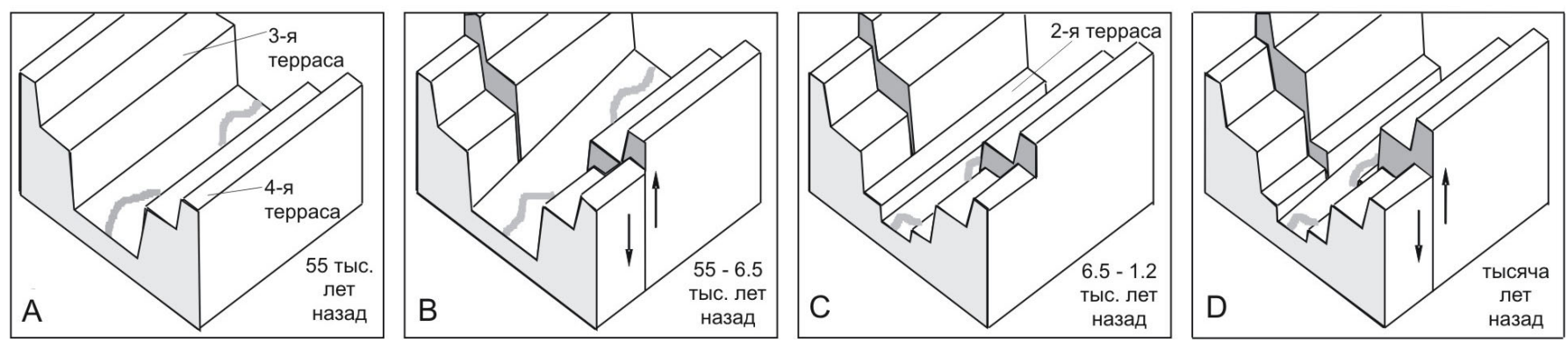

Рис. 1. Схема становления террасового комплекса устья долины р. Кынгарга, осложнённого сбросовым уступом.

А - более 55 тыс. лет назад были сформированы 4-я и 3-я террасы. В - в течение временного отрезка, продолжительностью не менее 50 тыс. лет, 4-я и 3-я террасы были сброшены на 7.5-8.0 м в результате нескольких сильных палеоземлетрясений. С - в период между 6.5 и 1.2 тысячами лет назад формируется 2-я терраса. D - около тысячи лет назад происходит сброс террас на 1.3 м

Fig. 1. Scheme showing evolution of terraces in the valley of the Kyngarga River outlet. The terraces are complicated with fault benching. A - Terraces 4 and 3 were formed over 55 thousand years ago. B - By several strong paleoearthquakes, which occurred within a period of at least 50 thousand years, terraces 4 and 3 were shifted down by 7.5-8.0 m. C - Terrace 2 was formed in a period between 6.5 and 1.2 thousand years ago. $\mathrm{D}$ - Around one thousand year ago, the terraces were shifted down by $1.3 \mathrm{~m}$.

жённую оценку возраста уступа, однако для районов с повторяемостью разрывообразующих землетрясений в тысячи лет морфометрический метод применим и для сегментации уступов, и для определения многоактности их формирования.

Под морфометрией сейсмодеформаций следует понимать не только исследование развития сейсмогенных уступов в зависимости от их возраста и начальных параметров (высоты и крутизны уступа). Это, прежде всего, анализ всех морфологических изменений, связанных с сейсмичностью. Существуют различные подходы к решению палеосейсмологических задач с применением морфометрического контроля сейсмогенных деформаций элементов рельефа. Вот лишь три характерных примера.

P. Уоллес [Wallace, 1980] для расчёта повторяемости сильных землетрясений в зоне разлома СанАндреас детально исследовал связь между сейсмогенными смещениями речных русел и длиной рек, пересекающих в 130 местах разлом Сан-Андреас.

Широко используются возможности разделения многоактных сейсмотектонических уступов в местах пересечения сейсмогенными разрывами долин рек и ручьев с террасовыми комплексами (рис. 1) [Huконов, 1981; Paleoseismology, 1996]. Здесь разновозрастные импульсные подвижки отражены в количестве и высоте террас, обусловленных врезами в результате изменившегося базиса эрозии от этих подвижек. По результатам изучения террас было установлено четыре-шесть фраз разрывообразования по разлому Ферейс-Крик и три фразы или более по разлому Долины смерти в Калифорнии [Brogan et al., 1991]. По количеству террас на поднятом крыле разлома Хелан в Китае (эпицентральная область землетрясения 1739 г. с M=8) устанавливается три разрывообразующих палеособытия [Deng, Liao, 1996].

Интересный подход к определению возраста палеоземлетрясений применён китайскими учеными. Ц. Ян и др. [Ян и др., 1985] изучали голоценовую активность передового разлома хребта Хэланьшань на основе морфометрических данных по точкам перегиба и террасам, развитым вдоль оврагов, пересекающих склоны гор, а также по крутизне различных частей сбросовых уступов. Авторы выделили восемь крупных голоценовых землетрясений, последнее из которых привело к смещению Великой Китайской стены.

Среди отечественных учёных С.В. Ласточкин [Ласточкин, 1981, 1982] первым вывел функциональную зависимость возраста сейсмогенной деформации от скорости изменения угла наклона поверхности стенок раздвигов в средних и близких к ним грунтах. Работы С.В. Ласточкина интересны тем, что они основаны на результатах полевых наблюдений разрывов сдвигового и взбросо-сдвигового типа, образовавшихся в двадцатом столетии при Болнайском (1905 г.), Гоби-Алтайском (1957 г.), Могодском (1967 г.), Тахин-Шарском (1974 г.) и других землетрясениях.

Практически все выделенные в Прибайкалье сейсмогенные структуры имеют яркую морфологическую выраженность. Отсутствие данных о возрасте палеоземлетрясений, основанных на радиоуглеродном датировании, а также о числе сильных палеоземлетрясений, сформировавших или обновивших каждую из сейсмогенных структур, не позволяло до недавнего времени применять данные морфометрии для датирования сейсмогенных уступов. Первая работа в этом направлении была проведена в процессе изучения Восточно-Саянской палеосейсмогенной структуры [Чипизубов, Смекалин, 1994]. Массовое морфологическое профилирование сейсмогенных уступов вместе с опорными абсолютными датировками позволило диффреренцировать выраженные в рельефе палеосейсмогенные дислокации на отдельные разновозрастные фрагменты и, наоборот, иногда объединять изолированные отрезки в единую дислокацию. В последнем случае для контроля, исключающего объединение палеосейсмодислокаций, связанных со сближенными во времени палеоземлетрясениями, используются соотно- 


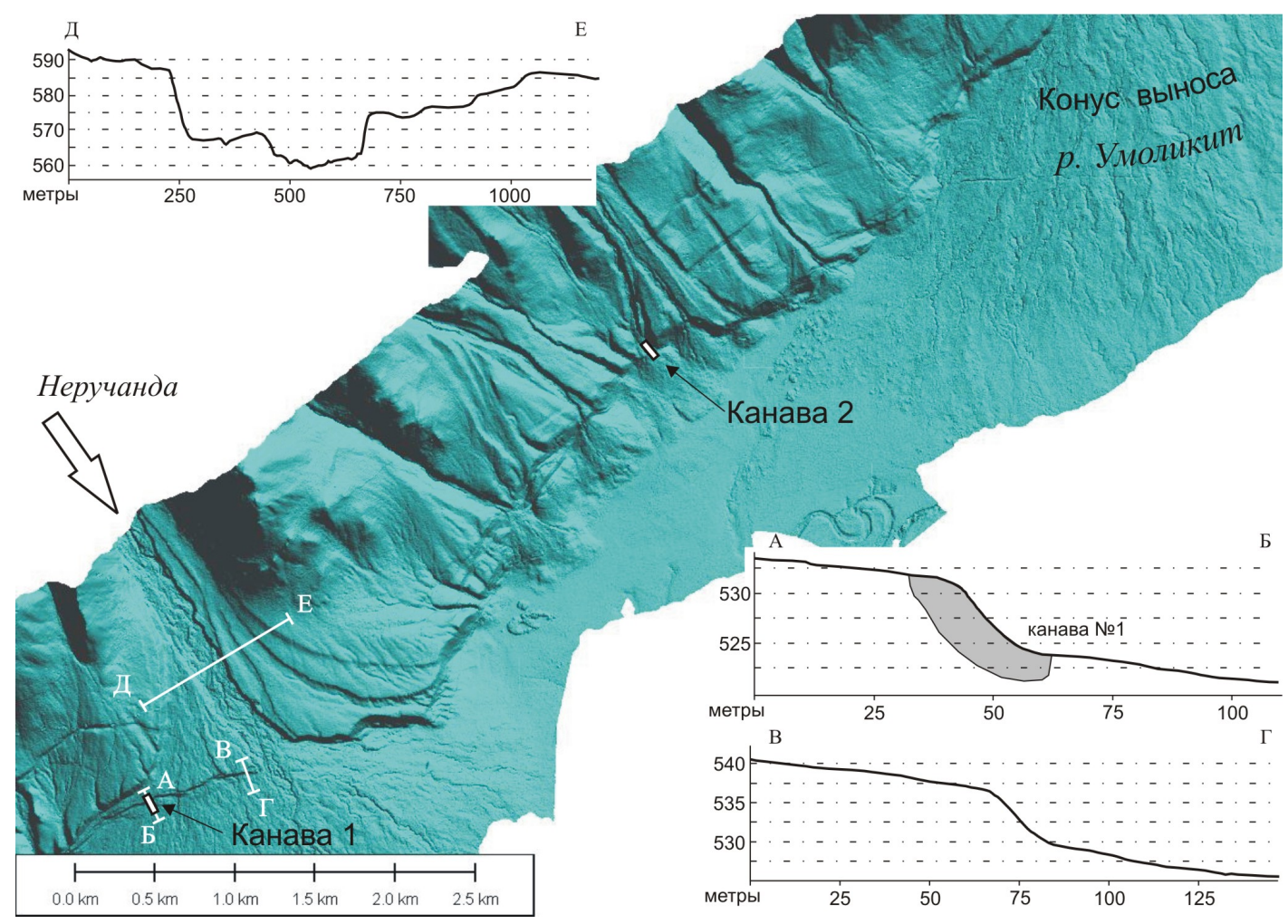

Рис. 2. Фрагмент центрального участка Кичерского сброса.

Показаны профили, выполненные программой обработки трёхмерной цифровой модели поверхности. Профили А-Б и В-Г пройдены через сейсмогенный уступ, деформирующий конус выноса р. Неручанда. Амплитуда вертикального смещения выдержана на всём протяжении дислокации в пределах пролювиальных отложений. Профиль Д-Е пройден поперёк комплекса речных террас. Линия профиля А-Б совпадает с местом проходки одной из канав.

Fig. 2. Fragment of the central part of the Kichera normal fault.

Profiles reconstructed by 3D digital modeling of the surface are shown. Profiles A-E and B- $\Gamma$ go across the seismogenic bench which deforms the alluvial cone of the Neruchanda River. Vertical displacement amplitudes are within the proluvial deposits. Profile Д-E goes across the river terraces. Profile A-Б coincides with a trench.

шения между протяженностью и амплитудой смещения, характерные для современных сейсмодислокаций [Чипизубов, 1998]. Даже при массовом отборе проб на радиоуглеродный анализ точность абсолютных датировок (в лучшем случае $\pm(25-100$ лет) не разрешает проблемы сближенных во времени палеоземлетрясений. За период в 50-200 лет может произойти несколько разрывообразующих событий, наращивающих зону новообразованных разрывов по длине, что неоднократно наблюдалось в последнее столетие.

Морфометрический метод постоянно развивается, как совершенствуется и применяемая в полевых условиях измерительная техника. Мерные линейки и угломеры заменены комбинацией теодолита и лазерного дальномера (прибор Precision Total Station Wild TC 2002), позволяющих в машиночитаемой форме получить пространственное положение наблюдаемых точек земной поверхности. В результате компьютерной обработки полученных данных (используется программа «Surfer») создаются профили и топографические карты небольших участков местности и их трёхмерные изображения [Дислокации..., 1998].

Сегодня всё чаще для изучения строения дисло- каций используют материалы лазерного сканирования земной поверхности различного уровня детальности. В сравнении с традиционной аэро- и космофотосъёмкой они обладают рядом несомненных преимуществ, позволяющих получить более надёжную и удобную в использовании (обработке и дешифрировании) цифровую модель местности. Применение средств фильтрации по последнему отклику освобождает изображения поверхности от растительного покрова, что являлось основной помехой для выделения и определения параметров сейсмодислокаций при дешифрировании аэрофотоснимков и при аэровизуальных наблюдениях (рис. 2). Высокая точность отображения рельефа -0.2 м по вертикали - даёт возможность построения профилей сечения и определения геометрических параметров дислокаций, на что раньше уходила значительная часть времени полевых исследований. Использование снимков лазерного сканирования уже на этапе внедрения их в практику сейсмогеологического метода позволило выделить ряд ранее не известных фрагментов сейсмогенного вскрытия в зонах палеосейсмогенных структур, а также линеаменты поверхности, интерпретируемые как возможно сейсмогенные [Смекалин и др., 2007]. Лазерную съёмку 
рельефа поверхности и дешифрирование цифровых моделей рельефа необходимо включить как элемент в сейсмогеологический метод, наряду с дешифрированием аэро- и космоснимков и аэровизуальным наблюдением. Подобные работы должны предшествовать полевым исследованиям, что значительно повысит их качество, результативность, сократит необходимое для их проведения время. Полезным может быть использование любых видов лазерного и радарного сканирования наземного, авиационного или спутникового базирования.

\section{МЕТОДЫ ПОЛУЧЕНИЯ АБСОЛЮТНОГО ВОЗРАСТА}

Важным моментом современных палеосейсмогеологических исследований должна стать их направленность на получение конкретных параметров палеоземлетрясений, включающих их место, возраст, периодичность и силу. Данные о палеоземлетрясениях и о строении палеосейсмогенных структур должны иметь ту достоверность, которая бы позволила использовать их как для решения задач долгосрочного сейсмического прогноза, так и для тектонофизических, геодинамических и других построений.

Оценивая достоверность получаемого возраста палеоземлетрясений методами абсолютных датировок, Дж. Мак-Калпин [Paleoseismology, 1996] на первые места ставит исторический и дендрохронологический методы. Исторический метод, а также его полевое дополнение - археосейсмология - особенно эффрективны на территориях, обжитых древними цивилизациями, например в Центральной Азии, на Кавказе, Ближнем Востоке [Корженков, Мазор, 2001; Никонов, 1977, 1981; Трифонов, Караханян, 2004]. Однако эти методы сильно ограничены небольшим временным диапазоном их применения. Для Прибайкалья этот интервал не превышает первые сотни лет. В Прибайкалье первые данные абсолютного возраста сейсмодислокаций были получены в конце 70-х годов дендрохронологическим методом. Для дислокаций Муйского землетрясения (1957 г.) ошибка определения возраста составила 1-2 года. Для наиболее поздней активизации Таксимской палеосейсмодислокации установлен возраст 253-256 лет [Ружич и др., 1982].

Большим шагом вперёд в развитии палеосейсмологии можно считать начало систематического изучения сейсмодеформаций в разрезах канав, которое позволяет подтвердить их сейсмогенность путём вскрытия сместителя и приуроченных к нему сейсмогенных фаций осадков. Применение методов определения абсолютного возраста погребённых почв и других видов осадков дает возможность датировать сейсмодеформации и, следовательно, палеоземлетрясения. Определение возраста и кинематики подвижек на отдельных участках активных разломов стало одним из методов их детальной сегментации. Возможности сейсмогеологии значительно расширены применением методов малоглубинной геофизики, которые позволяют проследить сейсмогенные разрывы на глубину до 100 м и более, установить связь наблюдаемых на поверхно- сти дислокаций с активными тектоническими разломами (рис. 3).

Первые работы по исследованию геологических проявлений сильных землетрясений были проведены американцем Г.К. Жилбертом. Работая во внутренних бассейнах Американского Запада, он более 130 лет назад первым из геологов определил, что уступ в основании горного сооружения является доказательством роста хребта в результате движений по ограничивающему хребет разлому во время сильных землетрясений [Gilbert, 1875]. Зона Уосатчского разлома, особенно вблизи Солт Лэйк Сити, сыграла главную роль в сформулированной Г.К. Жилбертом теории о горных сооружениях и землетрясениях. В одной из своих работ [Gilbert, 1890] он приводит классическое описание молодого разломообразования, прослеживающегося вдоль Уоасатчского разлома, и впервые выделяет уступ сбросового типа как самостоятельный морфотектонический элемент. По оценке американских палеосейсмологов, Г.К. Жилберт показал экстраординарное понимание геологических процессов и принципов, на основе которых впоследствии развивались исследования по прогнозу сейсмической опасности. В одной из газетных статей 1883 г. Г.К. Жилбертом было сделано заявление о том, что землетрясение угрожает городу Солт Лэйк Сити. Интервалы повторяемости, время, прошедшее с момента последнего разрывообразующего события, сегментация разлома, структура разломной зоны, деформации грунтов и параметры землетрясений - все основные вопросы современной палеосейсмологии в той или иной форме рассматривались Г.К. Жилбертом [Lund, 1991; Wallace, 1987].

Одной из ранних палеосейсмологических работ можно считать также исследования Имамура Акицунэ, который изучал распределение многослойной осадочной толщи, пронизанной ходами и отверстиями, оставленными древними организмами, в плейстосейстовой области только что произошедшего Токийского землетрясения (1923 г.). По распределению слоёв учёный определил колебания поверхности моря в прибрежной зоне Японии. Основываясь на изменениях уровня поверхности моря, он пришёл к выводу о том, что в Токийском регионе в прошлом произошло четыре сильнейших землетрясения, подобных катастрофическому толчку 1923 г. [Гоюй, 1982]. Значительно позже другая величайшая сейсмическая катастрофа - Гоби-Алтайское 12-балльное землетрясение - послужила толчком к возникновению и развитию палеосейсмогеологического метода в СССР, а впоследствии и во всём мире.

На рубеже 60-х и 70-х годов XX столетия начинается современный этап в развитии палеосейсмологии. В Советском Союзе и Соединённых Штатах Америки практически независимо одно от другого формируются и развиваются самостоятельные научные направления. В США вскрытие дислокаций и изучение их строения в разрезах канав (метод «trenching») стали неотъемлемым элементом палеосейсмологических исследований уже в пору становления палеосейсмологии. Среди первых работ, 


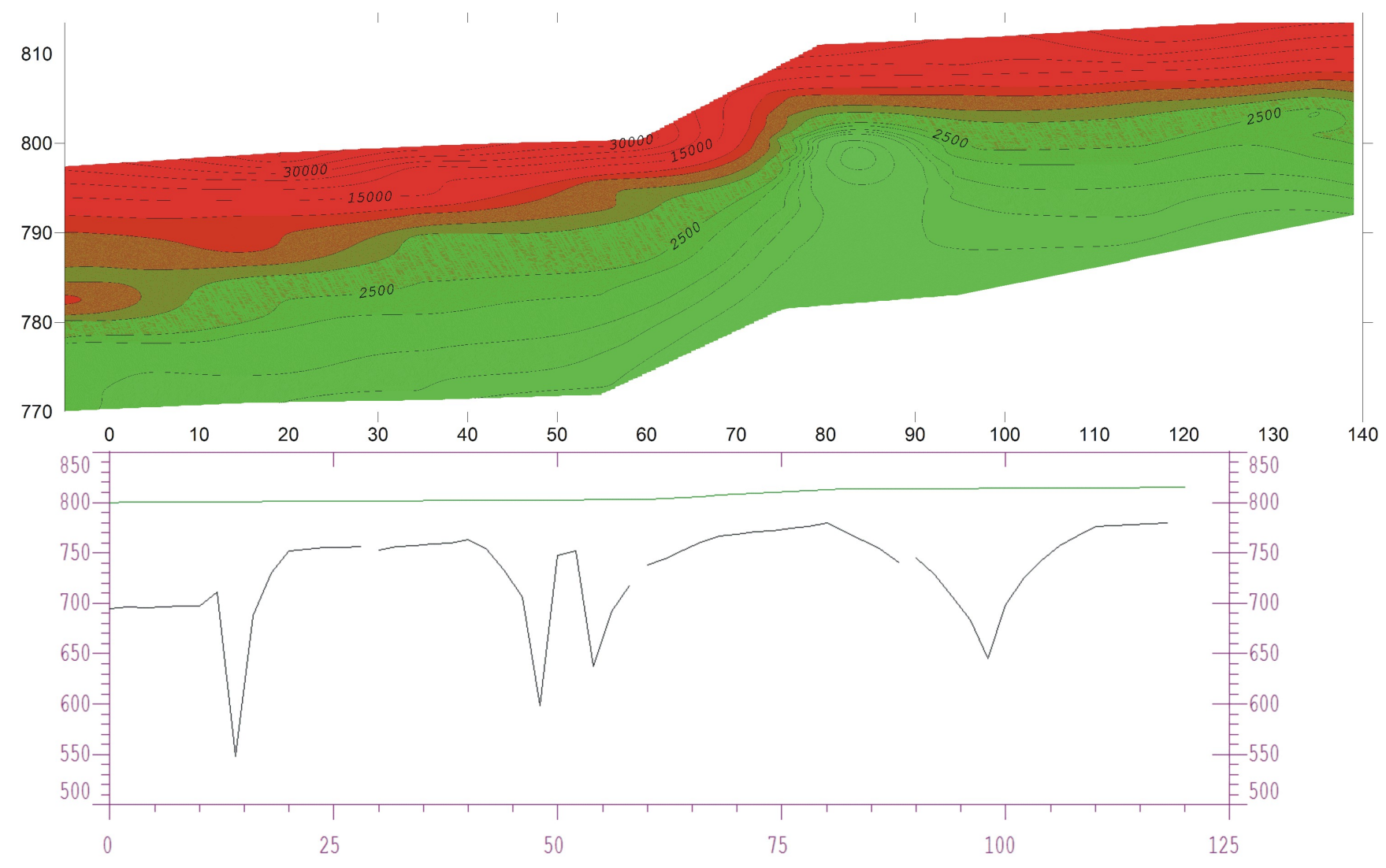

Разрез кажущихся сопротивлений по данным ДОЗ и преломляющие границы по данным КМПВ

Кичерская ПСС.

Конус выноса р. Неручанда.

Документировали В.П. Ёлкин, О.П. Смекалин, А.В. Чипизубов, В.С. Имаев, ноябрь, 2005 г.

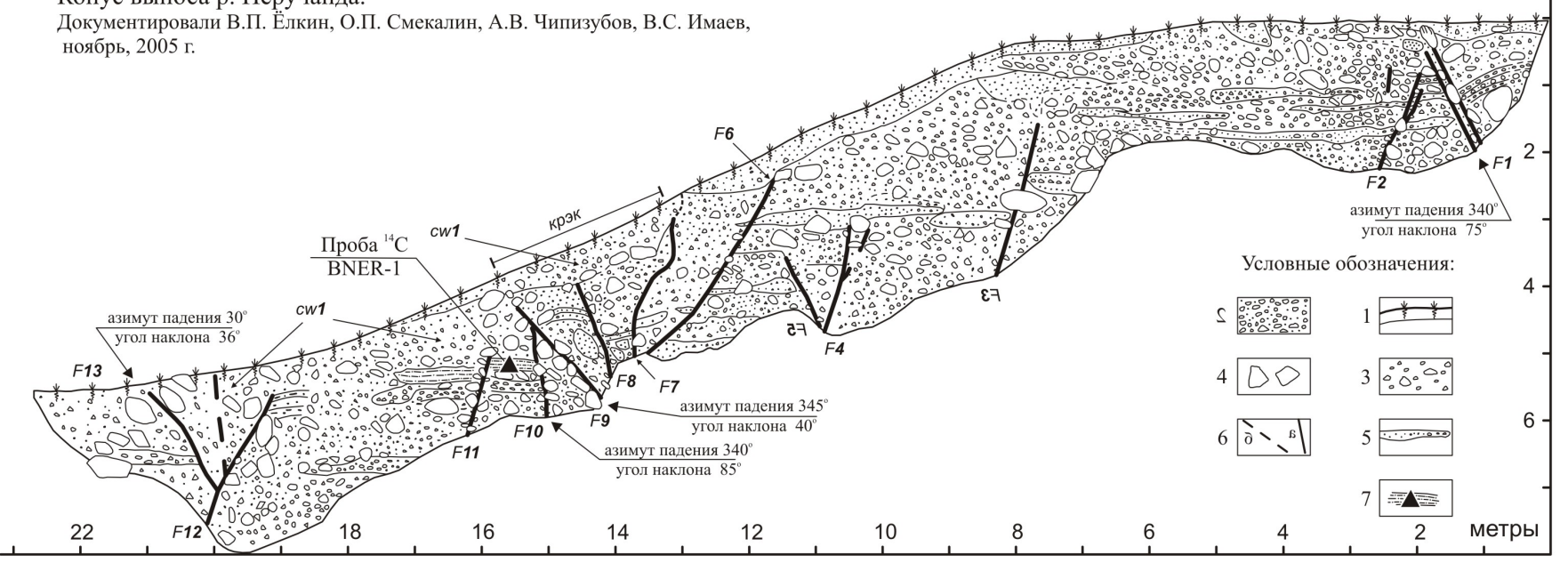

Рис. 3. Структура сейсмогенного сброса Кичерской структуры по результатам геофизических исследований и тренчинга.

Fig. 3. Structure of the seismogenic Kichera normal fault according to results of geophysical studies and trenching.

в которых были даны оценки возраста сейсмодислокаций по результатам их изучения в разрезах канав, можно упомянуть следующие.

После Южно-Калифорнийского землетрясения 1968 г. в горах Боррего (M=6.4) М. Кларк с соавторами [Clark et al., 1972] проанализировал деформационные явления в голоценовой толще, вскрытой разведочной канавой в зоне дробления сброса. Ра- диоуглеродное опробование показало, что между горизонтальными смещениями и возрастом слоёв имеется хорошо выраженная линейная связь. Установлено, что за последние 3000 лет движение крыльев разлома сопровождалось сравнительно сильными землетрясениями, происходившими примерно один раз в 200 лет. Открытая М. Кларком чёткая повторяемость землетрясений является 
первой установленной закономерностью сейсмической деятельности в Южной Калифорнии.

Дж. Симс, проводя исследования нарушений в толще ила в водохранилище, находящемся в эпицентральной зоне землетрясения, произошедшего в 1971 г. в Сан-Фернандо, пришёл к выводу о неоднократности землетрясений в этом районе в прошлом [Sims, 1973, 1975].

В 1978-1980 годах К. Си [Sieh, 1978, 1981], изучив разрезы нескольких разведочных канав и выполнив датирование радиоуглеродным методом, первым осуществил системное палеосейсмогеологическое исследование разлома Сан-Андреас в Калифорнии. Он выявил остаточные деформации палеосейсмической деятельности в болотных отложениях позднего голоцена в зоне Портеси северовосточнее Лос-Анджелеса. К. Си выявил восемь сильных сейсмических событий, произошедших в данном районе начиная с VI в. Радиоуглеродным методом определено приблизительное время этих землетрясений, а анализ амплитуд деформаций дал возможность оценить силу событий.

Как видно из приведённых примеров, задачи определения возраста и повторяемости палеоземлетрясений являлись приоритетными уже на заре развития палеосейсмологии. Со временем расширяется география сейсмогеологических исследований, увеличивается число методов, применяемых для решения сейсмогеологических задач, в том числе и для определения возраста палеоземлетрясений.

Принципы датирования палеоземлетрясений по данным вскрытия сейсмогенных деформаций освещены в работах [Forman et al., 1988; Machette, 1987; McCalpin, 1989; Paleoseismology, 1996; и дp.]. Они являются общими для палеоземлетрясений с любым генетическим типом сейсмогенной подвижки и приповерхностного геологического строения. Любые вариации методов датирования обусловливаются индивидуальными особенностями строения дислокаций в каждом конкретном случае. Возраст палеоземлетрясения определяется как начало формирования сейсмогенных фаций осадков, генетически связанных с палеоземлетрясением, на различных участках разлома, в виде временного интервала, продолжительность которого отражает степень достоверности данных и погрешности в датировании образцов. В настоящее время в большинстве случаев в качестве материала для датирования используют гумусированные слои, что предопределяет следующий общепринятый подход к интервальной оценке возраста палеоземлетрясения. Возраст палеособытия выражается в виде временного интервала, ограниченного, с одной стороны, возрастом самого молодого из датированных слоёв, дислоцированных подвижкой (нижняя граница интервала), и с другой - возрастом наиболее древнего из датированных горизонтов, перекрывающих сейсмогенные осадки (верхняя граница интервала). В качестве наиболее распространённой формы сейсмогенных осадков в разрезах канав выступают отложения коллювиального клина (the colluvial wedge). Общий принцип датирования палеособытия основан на отношении к коллювиальному клину как к единому реперу сейсмического смещения, относительно которого возможна корреляция отложений периодов сейсмического покоя.

Среди основных типов сейсмогенных деформаций наиболее простым для датирования является случай сбросовой подвижки на горизонтальной или слабонаклонной поверхности (речные террасы, конусы выноса). При такой подвижке образуется уступ с так называемой «свободной поверхностью» [Wallace, 1977], который начинает интенсивно разрушаться, особенно в верхней части, вблизи бровки. Продукты разрушения уступа в виде обломков различной величины скапливаются на поверхности опущенного блока в основании уступа. Часть свободной поверхности захороняется в ненарушенном состоянии, образуя резкий контакт между породами лежачего блока и коллювиального клина (рис. 3). По мере выполаживания уступа и денудации его свободной поверхности завершается формирование обломочной фации коллювиального клина и начинается накопление продуктов размыва склоновых отложений, представленных, как правило, суглинками, супесями, песками. При благоприятных условиях фрормируются почвенные горизонты. Накопление осадков верхней фации коллювиального клина происходит при активном участии склоновых процессов, таких, как плоскостной смыв, солифлюкция и др. На скорость этих процессов, а также на мощность отложений данной фации осадков, вероятно, оказывают влияние и криповые движения по сбросу. При незначительном наклоне исходной поверхности граница между двумя фациями коллювиального клина устанавливается довольно точно.

Значительные перерывы между сейсмическими подвижками способствуют развитию на выположенной поверхности уступа достаточно мощных почвенных горизонтов, которые могут быть датированы по ${ }^{14} \mathrm{C}$. Большинство тектонических уступов претерпевают неоднократное обновление, что приводит к формированию новых коллювиальных клиньев. Таким образом, определение возраста палеоземлетрясения сводится к выделению и датированию соответствующего ему коллювиального клина. Коллювиальные клинья характерны для сейсмодеформаций любого типа, имеющих вертикальную составляющую подвижки или образующих свободные поверхности (например, сдвиги по резко расчленённому рельефу).

В общем случае количество коллювиальных клиньев соответствует числу сейсмогенных подвижек по разлому. Как уже указывалось, полный цикл развития коллювиального клина включает три основных фразы: формирование фрации обломочного материала, частичные разрушение и захоронение свободной поверхности уступа, накопление стратифрицированной тонкообломочной толщи. По данным P. Уоллеса [Wallace, 1977], свободная поверхность большинства уступов нормальных сбросов подвергается денудации в течение нескольких сотен лет, а уступы в скальных породах - нескольких тысяч лет, то есть при достаточно низком периоде повторяемости землетрясений цикл развития коллювиального клина будет неполным, а граница между двумя 
коллювиальными клиньями неясной (повышается вероятность пропуска сейсмического события). Кроме того, необходимо иметь в виду, что для сбросовых деформаций, расположенных в основании значительных по высоте сейсмотектонических уступов, а также в основании крутых горных склонов, отложения коллювиальных клиньев могут соседствовать с коллювиальными осадками несейсмогенного происхождения. К ограничивающим применение тренчинга факторам среди прочих можно отнести и следующие. C каждым последующим событием усложняется строение деформаций, связанных с предшествующими событиями. Практика показывает, что число поддающихся интерпретации палеособытий в разрезе канавы не превышает 2-3. Также технологически невозможно в разрезе канавы проследить строение сместителя и перемещение опорных горизонтов на глубины более 4-5 м.

В случаях, когда сейсмогенная деформация вскрыта одной канавой или для её датирования используется одна-две радиоуглеродных пробы, за возраст палеоземлетрясения принимают датировку погребённой почвы, разорванной сейсмической подвижкой. Проведённые нами исследования показали, что на разных участках разлома почвы, деформированные единым событием, имеют различный возраст формирования, так как консервация почвенных горизонтов может происходить вследствие активизаций склоновых процессов, не связанных с сейсмическими проявлениями. Возможны ситуации (например, когда исходная поверхность слабонаклонна или горизонтальна, а амплитуда подвижки незначительна), при которых деформированные почвы ещё длительное время остаются на поверхности. Поэтому при использовании радиоуглеродных датировок необходимо самым тщательным образом изучать и учитывать условия формирования, деформирования и захоронения почвы. Весьма полезной бывает реконструкция разреза для времени, предшествовавшего палеоземлетрясению.

Сейсмогенные сбросы часто осложнены грабенами в основании уступов, редко на их склонах. Такие грабены (сейсмогенные рвы) представляют естественную преграду для плоскостного смыва и для временных водотоков. Часто грабены в виде отрицательных микроструктур сохраняются в течение всего промежутка времени, разделяющего палеоземлетрясения. В них фрормируются относительно мощные почвенные горизонты, удобные для датирования по ${ }^{14} \mathrm{C}$. Во время землетрясения дно грабена покрывается коллювиальными осадками, происходит захоронение почвенного горизонта, а в период стабилизации склоновых процессов формируется новая почва. Таким образом, датирование погребённых почвенных горизонтов, вскрытых в теле грабена, также используется для определения возраста палеоземлетрясений.

К более сложному по строению и интерпретации типу сейсмогенных деформаций относятся деформации, связанные со взбросовыми подвижками и близкими к ним по генезису взбросо-сдвигами. Рассматривается несколько видов взбросовых деформаций и схем их постадийного формирования [Hull,
1987; McCalpin, 1989]. Важную роль в формировании взбросовых деформаций играет угол падения сместителя в приповерхностном слое и амплитуда смещения при отдельных подвижках. Дж. Мак-Калпин считает, что для выделения и датирования отдельных событий в разрезах взбросовых деформаций приемлема модификация способа, основу которого составляет выделение из разреза циклов осадков, соответствующих коллювиальным клиньям. При анализе разрезов взбросовых дислокаций в Южной Исландии и Новой Зеландии [Hull, 1987] было отмечено широкое развитие изгибовых деформаций непосредственно у земной поверхности вблизи границы сместителя.

При датировании сейсмодеформаций в разрезах канав за рубежом используют также термолюминесцентный метод, который по своей популярности среди палеосейсмологов уступает лишь радиоуглеродному. В то же время Дж. Мак-Калпин и С. Форман указывают на сложности, связанные с надёжностью применения этого метода, вызванные прежде всего тем, что времени формирования коллювия оказывается недостаточно для светового облучения осадка [McCalpin, Forman, 1988]. В практике отечественных сейсмогеологических работ термолюминесцентный метод практически не использовался.

\section{ТРЕНЧИНГОВЫЕ РАБОТЫ В ПРИБАЙКАЛЬЕ}

В конце 80-х годов по инициативе В.С. Хромовских в Южном Прибайкалье началось планомерное систематическое изучение сейсмогенных деформаций в разрезах горных выработок методами тренчинга, ставшими к этому времени основными приемами палеосейсмологических исследований за рубежом [McCalpin, Khromovskikh, 1995]. В.С. Хромовских в русскоязычном варианте предложен термин «тренчинг» для определения всего комплекса работ, связанных со вскрытием сейсмогенных деформаций горными выработками [Хромовских и др., 1993]. Тренчинг (англ.) - проходка траншей, канав; применительно к палеосейсмологическим исследованиям термин используется с конца 70-х годов (например, в названии работы [Hatheway, Leighton, 1979]). Сегодня практически во всех зонах сейсмоактивных разломов проводятся подобные тренчинговые работы. Горные выработки используют для изучения плоскостей сейсмотектонических смещений и приуроченных к ним сейсмогенных фаций осадков.

В Прибайкалье в конце 80-х - начале 90-х годов, в период наиболее активного применения тренчинга, было пройдено около 100 канав в зонах разломов: Главного Саянского (Восточно-Саянская палеосейсмодислокация и активизированный фрагмент вблизи г. Байкальска), Тункинского (Торская и Аршанская палеосейсмодислокации), Обручевского сброса (Сарминская палеосейсмодислокация), Дельтового (структуры, контролирующие развитие заливов Провал, Посольский и Истокский на восточном берегу Байкала), а также Танхойской структуры в привершинной части хребта Хамар-Дабан. В последующие годы география применения тренчин- 
га в Прибайкалье расширялась. Были вскрыты активные и предположительно активные фррагменты в зонах Окино-Жомболокского, Баргузинского, Ангарского, Северо-Байкальского, Кичерского и Хамбинского разломов.

Результаты сейсмогеологических исследований в Прибайкалье с применением тренчинга отражены в целом ряде работ [Дельянский, 1993; Дельянский и др., 1992; Дельянский, Хромовских, 1994; Ружич и др., 1997; Смекалин и др., 2007; Хромовских и др., 1996; Чипизубов и др., 2007; Чипизубов и др., 2000; Чипизубов и др., 1994; Чипизубов, Смекалин, 1999; Чипизубов, Смекалин, 1994; McCalpin, Khromovskikh, 1995; и др.].

За последние 35-40 лет в Прибайкалье было выделено и с разной степенью детальности изучено 73 сейсмотектонических палеосейсмодислокации. Однако из-за отсутствия достаточных данных о сейсмогенности (в том числе полученных с помощью современных методов исследования) в последний уточненный каталог палеосейсмодислокаций не вошло более половины из них [Хромовских, 1995; Хромовских и др., 1993].

Параметры этих палеосейсмоструктур (амплитуды смещения до 10-20 м и более при протяженности от 1.2 до 20-31 км), приведенные в первоисточниках [Сейсмическое районирование..., 1977; Сейсмотектоника..., 1968], не согласуются с характеристиками сейсмодислокаций исторического периода и прежде всего с соотношением амплитуд и протяжённостей разрывов. Согласно современным представлениям [Стром, 1993, 1998; Чипизубов, 1998], это может быть объяснено как различной степенью сохранности отдельных фрагментов дислокаций (занижение параметра «длина»), так и отсутствием данных о многоактности их активизации (завышение параметра «амплитуда»).

Палеосейсмологическими исследованиями за последние годы нами было выявлено несколько новых палеосейсмодислокаций (Кичерская, Дзелиндинская, Устьдзелиндинская, Котельниковская, Окинская, Восточно-Саянская и другие - без названий), а также уточнены параметры многих известных. В зонах Тункинского, Баргузинского, СевероБайкальского и Приморского разломов сейсмотектонические деформации обнаружены на значительных отрезках в перерывах между известными палеосейсмодислокациями. При этом вновь выявленные палеосейсмодислокации в большинстве случаев хорошо дешифрируются на аэрофотоснимках (табл. 2).

В первой группе содержатся палеосейсмодислокации, с которыми однозначно связаны исторические землетрясения. Дислокации Окинской структуры, возможно, связаны с землетрясением 3 марта 1859 г. [Чипизубов, Серебренников, 1990], а таковые Таксимской - с землетрясением 25 февраля 1725 г. [Ружич и др., 1982]. Ранее землетрясение 1725 г. связывалось с Чино-Вакатской палеосейсмодислокацией [Новый каталог..., 1977; Сейсмическое районирование..., 1977] без какой-либо ее абсолютной датировки. Однако данная дислокация в лучшем случае является многоактной, требующей дополнительного изучения.

Ко второй группе палеосейсмогенных деформаций относятся деформации, у которых имеются одноактные фрагменты. Среди последних имеются как те, которые, возможно, представлены двумя различными палеосейсмодислокациями, так и отдельные дислокации, являющиеся фрагментами единой. Например, не исключено, что Солонцовая, Среднекедровая (рис. 4, 5) и Хибиленская палеосейсмодислокации образовались при одном палеоземлетрясении, на что указывалось ранее [Сейсмотектоника..., 1968]. Подобное предположение высказывалось относительно Аршанской и Торской дислокаций [Хромовских и др., 1993]. Велика вероятность того, что двойные сейсмогенные уступы баргузинских палеосейсмодислокаций (Нестериха, Саранхур, Алла+Сухитке и южный фланг Дырен) образовались при двух мощных палеоземлетрясениях [Чипизубов и др., 2000], возраст которых по недавно полученным радиоуглеродным датировкам составляет 4.5 и 9.0 тыс. лет.

Таким образом, палеосейсмогенные дислокации, включённые в первые две группы, состоят из фрагментов, каждый из которых образовался, определенно, при одном землетрясении. Поскольку повторяемость разрывообразующих землетрясений практически в одних и тех же местах очень редка (сотни, а то и тысячи лет), то дислокации со специфической плановой структурой, образовавшиеся при разных землетрясениях, будут очень заметно отличаться одна от другой по сохранности. Такие случаи отмечались при изучении прибайкальских палеосейсмодислокаций [Геология..., 1985; Чипизубов, Серебренников, 1990; Чипизубов и др., 1994], а также во многих регионах мира [Хромовских, 1989]. В случае же, когда дислокации наращиваются по длине активного разлома при близких по времени землетрясениях, общая длина вскрывшегося разлома будет приниматься за одноактную подвижку. Однако при этом протяженность дислокаций и их амплитуды смещений будут находиться в большом несоответствии, так же, как и магнитуды $(M)$ палеоземлетрясения, рассчитанные по длине $(L)$ и по амплитуде (D) дислокаций.

Магнитуды палеоземлетрясений, связанных с палеосейсмодислокациями первых двух групп, рассчитывались как по длинам, так и по амплитудам смещения сейсморазрывов по фрормулам:
1) $M=0.96 \mathrm{LgD}+6.7$
2) $M=1.86 \mathrm{LgL}+4.16$
3) $M=0.93 \mathrm{LgD}+6.86$;
4) $M=0.91 \mathrm{LgL}+5.52$
5) $M=1.1 \mathrm{LgD}+7.0$;
6) $M=1.07 \mathrm{LgL}+5.65$ (табл. 2).

К третьей группе (табл. 2) относятся палеосейсмодислокации, у которых отсутствуют или не зафиксированы одноактные фрагменты, и палеосейсмодислокации, вызывающие сомнения и требующие дополнительных исследований. Эти сомнения обусловлены тем, что микроформы рельефа почти у всех этих дислокаций прослежены только в местах 
Т а б л и ц а 2. Палеосейсмодислокации Прибайкалья

T a b l e 2. Paleoseismic dislocations in the Pribaikalie.

\begin{tabular}{|c|c|c|c|c|c|c|c|c|c|}
\hline \multirow[t]{2}{*}{ № $п / п$} & \multirow[t]{2}{*}{ Название ПСД } & \multicolumn{2}{|c|}{$\begin{array}{c}\text { Координаты центра } \\
\text { широта долгота }\end{array}$} & \multicolumn{2}{|c|}{$\begin{array}{c}\text { Амплитуда смещения } \\
\text { (D) в м }\end{array}$} & \multirow[t]{2}{*}{ Длина (L) в км } & \multicolumn{2}{|c|}{$\begin{array}{l}\text { Магнитуда } \\
\text { (М) по }\end{array}$} & \multirow[t]{2}{*}{ Источники } \\
\hline & & $\varphi$ & $\lambda$ & верт. & гор. & & & L & \\
\hline 1 & 2 & \multicolumn{2}{|c|}{3} & 4 & 5 & 6 & \multicolumn{2}{|c|}{7} & 8 \\
\hline \multicolumn{10}{|c|}{ Группа І. Дислокации, связанные с землетрясениями исторического периода } \\
\hline 1.* & Окинская I (1859) & 52.8 & 100.0 & 1.5 & Л 2 & 24 & $7.3^{3)}$ & $6.7^{4)}$ & 14 \\
\hline 2.* & Восточно-Саянская & 51.82 & 103.32 & $4-5$ & Л 10 & 60 & $8.0^{5)}$ & $7.6^{6)}$ & 15 \\
\hline 3.* & Котельниковская & 55.05 & 108.91 & 1.5 & - & 3 & $6.8^{1)}$ & $5.0^{2)}$ & 2 \\
\hline 4.* & Ковоктинская & 56.12 & 113.03 & $7(4)$ & - & 28 & $7.5^{1)}$ & $6.9^{2)}$ & 2.3 .8 \\
\hline 5. & Верхнеянчуканская & 56.15 & 112.87 & 3 & Л & 9 & $7.3^{3)}$ & $6.4^{4)}$ & 2.6 \\
\hline 6.* & Янчуканская & 56.17 & 112.59 & 4 & - & 13 & $7.3^{1)}$ & $6.2^{2)}$ & 2.8 .6 \\
\hline 7.* & Таксимская (1725) & 56.42 & 114.95 & $4-8$ & - & 15 & $7.4^{1)}$ & $6.3^{2)}$ & 5.6 \\
\hline 8. & Ульто & 56.30 & 114.83 & 3 & - & 1.5 & $7.3^{1)}$ & $4.5^{2)}$ & 2 \\
\hline \multicolumn{10}{|c|}{ Группа II. Дислокации, имеющие одноактные фрагменты } \\
\hline 9. & Окинская II & 52.85 & 100.15 & 5-6 & л & 90 & $7.8^{3)}$ & $7.7^{4)}$ & 14 \\
\hline 10.* & Аршанская & 51.90 & 102.36 & $9(4.5)$ & Л7.5 & 15 & $7.7^{3)}$ & $6.6^{4)}$ & 6.8 .9 \\
\hline $11 .^{*}$ & Торская & 51.84 & 102.80 & 4.5 & Л7.5 & 48 & $7.7^{3)}$ & $7.0^{4)}$ & 8.10 \\
\hline $12 .^{*}$ & Сарма & 53.1 & 106.85 & 2 & - & 3 & $6.9^{1)}$ & $5.0^{2)}$ & 8.10 \\
\hline 13.* & Солонцовая & 54.10 & 108.25 & $9(3-6)$ & $\Pi$ & 30 & $7.7^{3)}$ & $6.9^{4)}$ & 6.8 \\
\hline $14 .^{*}$ & Среднекедровая & 54.43 & 108.51 & 9 & - & $8-10$ & $7.6^{1)}$ & $6.0^{2)}$ & 6.8 \\
\hline 15. & Хибиленская & 54.77 & 108.81 & 8 & - & 22 & $7.6^{1)}$ & $6.6^{2)}$ & 6.8 \\
\hline 16. & Наледная & 55.53 & 108.89 & 2 & - & 4 & $6.9^{1)}$ & $5.0^{2)}$ & 2 \\
\hline 17.* & Нестериха -Улюн & 53.67 & 109.69 & 6.5 & - & 33 & $7.5^{1)}$ & $7.0^{2)}$ & 6.8 .13 \\
\hline $18 .^{*}$ & Тун-Саранхур-Сахули & 54.17 & 110.14 & 6.5 & - & 55 & $7.5^{1)}$ & $7.4^{2)}$ & 6.8 .13 \\
\hline 19.* & Шаманка & 54.53 & 110.43 & 9 & - & 5 & & $5.5^{2)}$ & 6.7 \\
\hline $20 .^{*}$ & Алла+Сухитке - Олос & 54.74 & 110.74 & 6.5 & - & 45 & $7.5^{1)}$ & $7.2^{2)}$ & 6.7 \\
\hline $21 . *$ & Олня & 55.76 & 113.43 & $5-6$ & Л6-7 & 29 & $7.7^{3)}$ & $6.8^{4)}$ & 2.6 \\
\hline $22 .{ }^{*}$ & Тилишминская & 55.75 & 115.25 & $15(2)$ & - & 15 & $6.9^{1)}$ & $6.3^{2)}$ & 2.6 \\
\hline $23 .{ }^{*}$ & Амнунда & 55.92 & 114.03 & 3.5 & - & 12 & $7.2^{1)}$ & $6.2^{2)}$ & 2.6 \\
\hline $24 .{ }^{*}$ & Кичерская & 56.02 & 110.09 & $4-6$ & - & 26 & $7.4^{1)}$ & $6.8^{2)}$ & 2.11 \\
\hline $25 .^{*}$ & Дзелинда & 56.09 & 110.62 & 6 & - & 20 & $7.4^{1)}$ & $6.8^{2)}$ & 2.11 \\
\hline 26 & Устьдзелиндинская & 56.0 & 110.6 & $5-8$ & - & 4 & $7.4^{1)}$ & $5.0^{2)}$ & 12 \\
\hline $27 . *$ & Итыкит & 56.27 & 113.45 & 5 & - & 10 & $7.4^{1)}$ & $6.0^{2)}$ & 2 \\
\hline $28 .^{*}$ & Муяканская & 56.15 & 113.80 & $2-5(4)$ & - & 31 & $7.3^{1)}$ & $6.9^{2)}$ & 2.6 \\
\hline 29. & Усмун & 56.17 & 115.50 & $3-4$ & - & 12 & $7.2^{1)}$ & $6.2^{2)}$ & 2.6 \\
\hline $30 .^{*}$ & Парамская & 56.63 & 115.43 & $20(5)$ & - & 21 & $7.4^{1)}$ & $6.8^{2)}$ & 2.6 \\
\hline 31. & Верхнесакуканская & 56.75 & 117.78 & 2 & - & 5 & $6.9^{1)}$ & $5.2^{2)}$ & 3.6 \\
\hline 32. & Среднесакуканская & 56.86 & 117.94 & $4-6$ & Л & 2.5 & $7.4^{3)}$ & $5.0^{4)}$ & 3.6 \\
\hline 33.* & Нижнеингамакитская & 56.56 & 118.29 & 1.5 & - & 1 & $6.8^{1)}$ & $4.2^{2)}$ & 3.6 \\
\hline $34 .{ }^{*}$ & Гусиноозерская & 51.13 & 106.25 & 4 & - & $2-3$ & $7.3^{1)}$ & $5.0^{2)}$ & 4.8 \\
\hline 35. & Ядрихинская & 50.16 & 110.35 & 3 & - & 1.5 & $7.1^{1)}$ & $4.5^{2)}$ & 6 \\
\hline \multicolumn{10}{|c|}{ Группа II. Дислокации многоактные } \\
\hline 36. & Китой-Кинская & 52.08 & 102.48 & $6-17$ & - & 4 & - & - & 6.9 \\
\hline $37 .{ }^{*}$ & Истокская & 52.15 & 106.25 & $10-12$ & - & - & - & - & 6 \\
\hline 38. & Намаракитская & 56.17 & 116.83 & 10 & - & 18 & - & - & 3.6 \\
\hline 39. & Кемен & 56.72 & 118.65 & 12.5 & - & 4 & - & - & 2.6 \\
\hline \multicolumn{10}{|c|}{ Группа III. Дислокации предполагаемые, требующие дополнительного изучения } \\
\hline 40. & Сархой & 52.20 & 99.42 & 2 & - & 2 & - & - & 6 \\
\hline 41. & Тустук & 52.35 & 100.40 & 4 & - & 6 & - & - & 6 \\
\hline 42. & Шумакская & 52.08 & 102.10 & 25 & - & 4 & - & - & 6.9 \\
\hline 43. & Ихэ-Ухгунь & 51.77 & 101.08 & $8 ?$ & Л 8? & 3.5 & - & - & 1 \\
\hline 44. & Олокитская & 56.53 & 110.26 & - & - & 2.2 & - & - & 2 \\
\hline 45. & Баронка & 56.45 & 117.05 & $8-10$ & Л 12 & 7.5 & - & - & 2.3 .6 \\
\hline 46. & Сюльбанская & 56.61 & 117.22 & 8 & - & 7 & - & - & 2.3 .6 \\
\hline 47. & Довачан & 56.36 & 117.38 & 7 & Л 12 & 12 & - & - & 2.3 .6 \\
\hline 48. & Чина-Вакатская & 56.49 & 118.50 & $8-9$ & $\Pi ?$ & 43 & - & - & 2.3 .6 \\
\hline 49.* & Эбгахлир & 57.28 & 119.30 & 4.5 & - & 7 & - & - & 2.6 \\
\hline $50 .^{*}$ & Медведь & 56.52 & 119.46 & 5.0 & - & 4 & - & - & 2.6 \\
\hline $51 .^{*}$ & Читкандинская & 56.98 & 119.57 & 2 & 1 & - & - & - & 8 \\
\hline 52. & Аргукан & 57.36 & 119.96 & $0.5-1$ & Л 1 & 3.5 & - & - & 2.6 \\
\hline
\end{tabular}

П р и м е ч а н и е. Серой заливкой выделены палеосейсмодислокации, которые, вероятно, являются отдельными фрагментами единой сейсмогенной структуры; звездочкой в первом столбце отмечены палеосейсмодислокации, вошедшие в последний ревизованный список [Хромовских и др., 1993]; в пятом столбце буквами Л и П обозначены направления горизонтальной составляющей подвижки, соответственно левая и правая, прочерками отмечены дислокации, для которых горизонтальные перемещения не установлены; в седьмом столбце верхним индексом обозначены номера уравнений регрессий, по которым рассчитана соответствующая магнитуда; в восьмом столбце приведены ссылки на печатные источники: 1 - Аржанникова, Аржанников, $1999 ; 2$ - Геология..., 1985; 3 - Живая тектоника..., 1966; 4 - Ласточкин, 1981; 5 - Ружич и др., 1982; 6 - Сейсмическое районирование..., 1977; 7 - Сейсмогеология..., 1981; 8 - Сейсмотектоника..., 1968; 9 - Сейсмотектоника..., 1975; 10 - Хромовских, $1995 ; 11$ - Хромовских и др., $1978 ; 12$ - Чипизубов, 1982; 13 - Чипизубов и др., 2000; 14 - Чипизубов, Серебренников, 1990; 15 - Чипизубов, Смекалин, 1999.

$\mathrm{N}$ o t e. Paleoseismic dislocations shown in grey are most likely to present individual fragments of the uniform seismogenic structure. Stars in the first column show paleoseismic dislocations included in the latest revision of the list published in [Khromovskikh et al., 1993]. In column 5, letters $\Omega$ and $\Pi$ refer to horizontal sinistral and dextral displacement, accordingly; boxes of dislocations with no horizontal movements identified 
are marked with dashes. In column 7, superscripts show numbers of regression equations used to calculate the corresponding magnitudes. Column 8 gives reference numbers to the following sources: 1 - Arzhannikova, Arzhannikov, $1999 ; 2$ - Geology ..., 1985; 3 - Live ..., 1966; 4 - Lastochkin, 1981; 5 - Ruzhich et al., 1982; 6 - Seismic ..., 1977; 7 - Seismogeology ..., 1981 ; 8 - Seismotectonics ..., 1968; 9 - Seismotectonics..., 1975; 10 - Khromovskikh, 1995; 11 - Khromovskikh et al., 1978; 12 - Chipizubov, $1982 ; 13$ - Chipizubov et al., 2000; 14 Chipizubov, Serebrennikov, 1990; 15 - Chipizubov, Smekalin, 1999.

выхода коренных пород и совсем не затрагивают рыхлые отложения с молодым возрастом заложения. Выделение одноактных и приблизительно одновозрастных подвижек для палеосейсмодислокаций этой группы является трудной, но выполнимой задачей [Чипизубов, 1998]. Она может быть успешно решена при проведении работ с массовым вскрытием сейсмогенных микроформ рельефа траншеями и отбором проб на радиоуглеродный анализ, совместно с проведением детальных исследований структурно-геологическими, геоморфологическими и геофизическими методами.

\section{ОПРЕДЕЛЕНИЕ МАГНИТУД ПАЛЕОЗЕМЛЕТРЯСЕНИЙ ПО ПАРАМЕТРАМ ПАЛЕОСЕЙСМОДИСЛОКАЦИЙ}

Исходя из самых общих представлений, масштаб сейсмотектонических деформаций (L, D, LD и размер отдельных элементов сейсмодислокаций) должен соответствовать величине разрывообразующего землетрясения. Корреляционные зависимости между вышеприведенными параметрами, особенно между магнитудой и длиной, приводились после Д. Точера многими исследователями [Лунина, 2001; Стром, Никонов, 1998; Чипизубов, 1998; Bonilla et al., 1984; Wells, Coppersmith, 1994].

В настоящее время $M$ досейсмостатистических землетрясений определяется преимущественно по протяженности палеосейсмодислокаций. Один из основоположников палеосейсмогеологического метода В.П. Солоненко [Сейсмическое районирование..., 1977] даже указывал, что амплитуды смещений для оценки $M$ палеоземлетрясений неприемлемы, так как они резко изменяются на коротких расстояниях и зависят от времени. Действительно, амплитуды смещений испытывают значительные изменения, но они не зависят от временного фрактора, как их поверхностное выражение в виде высоты

\section{A}

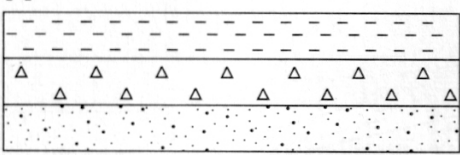

В (Событие 1)

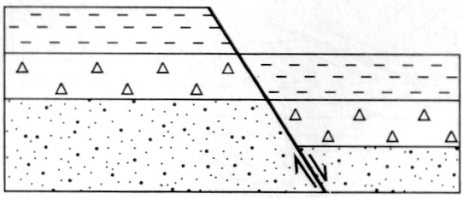

С (Формирование коллювиального
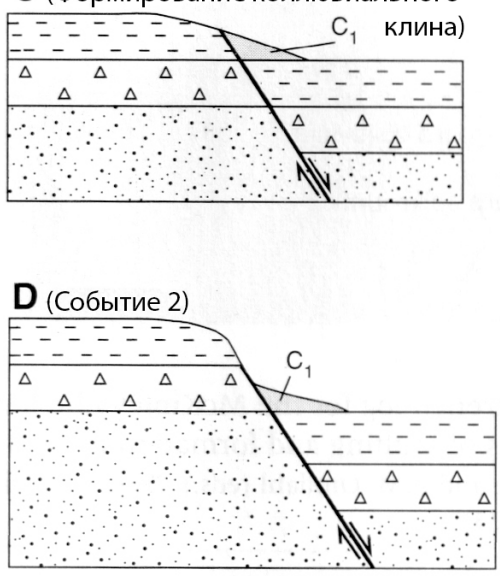

$\mathbf{E}$ (Формирование коллювиального
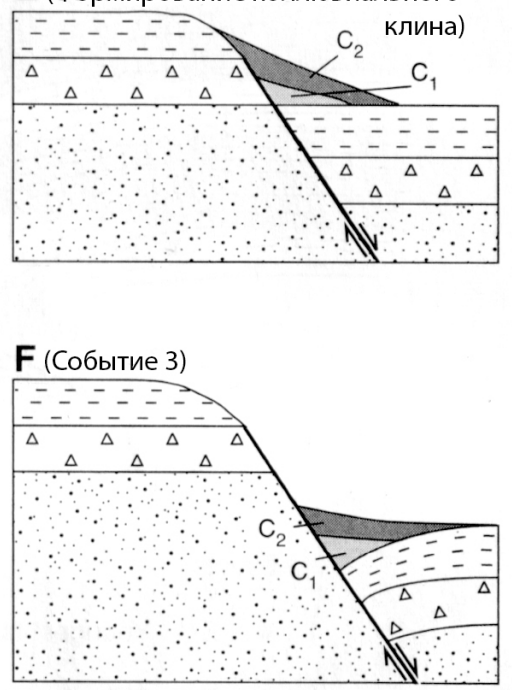

$\mathbf{G}$ (Формирование коллювиального

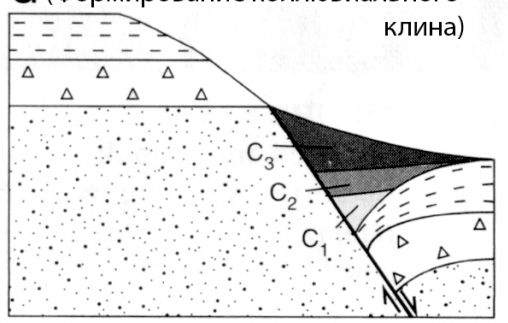

Рис. 4. Идеализированная модель развития сейсмотектонического уступа в результате трёх палеособытий сбросового типа. Каждое новое разрывообразование устанавливается по сформированному коллювиальному клину $\mathrm{C}_{1}, \mathrm{C}_{2}$ и $\mathrm{C}_{3}$, [Paleoseismology, 1996].

Fig. 4. Ideal model of seismotectonic benching, resulting from development of three paleofaults of normal type. Episodes of faulting are distinguished by shaped colluvial wedges $\mathrm{C}_{1}, \mathrm{C}_{2}$ and $\mathrm{C}_{3}$ [Paleoseismology, 1996]. 


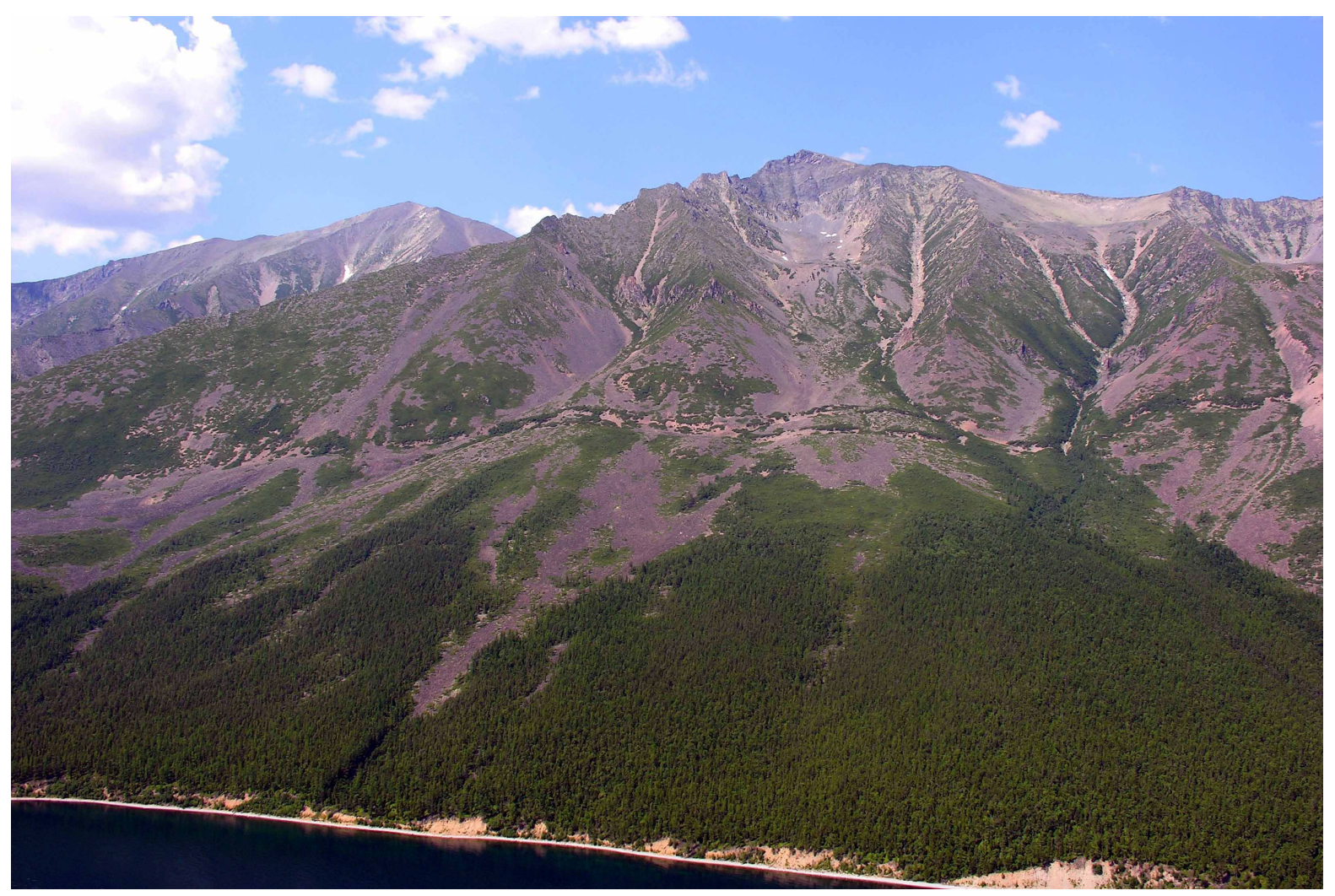

Рис. 5. Внешний вид палеосейсмодислокации Среднекедровая (полуперспективный аэрофотоснимок).

Fig. 5. General view of the Srednekedrovaya paleoseismic dislocation (semi-isometric aerial photograph).

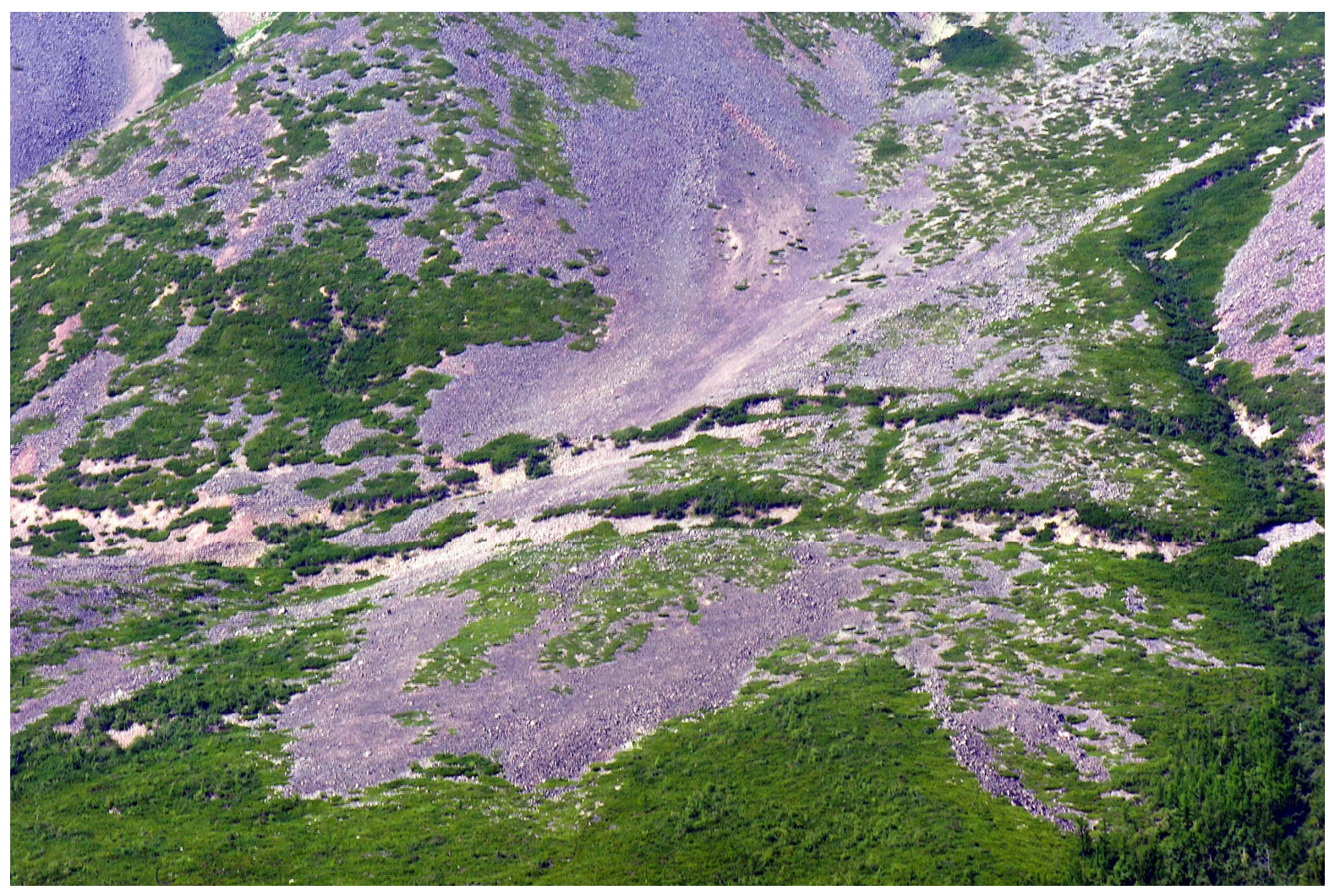

Рис. 6. Фрагмент палеосейсмодислокации Среднекедровая.

Fig. 6. Fragment of the Srednekedrovaya paleoseismic dislocation. 


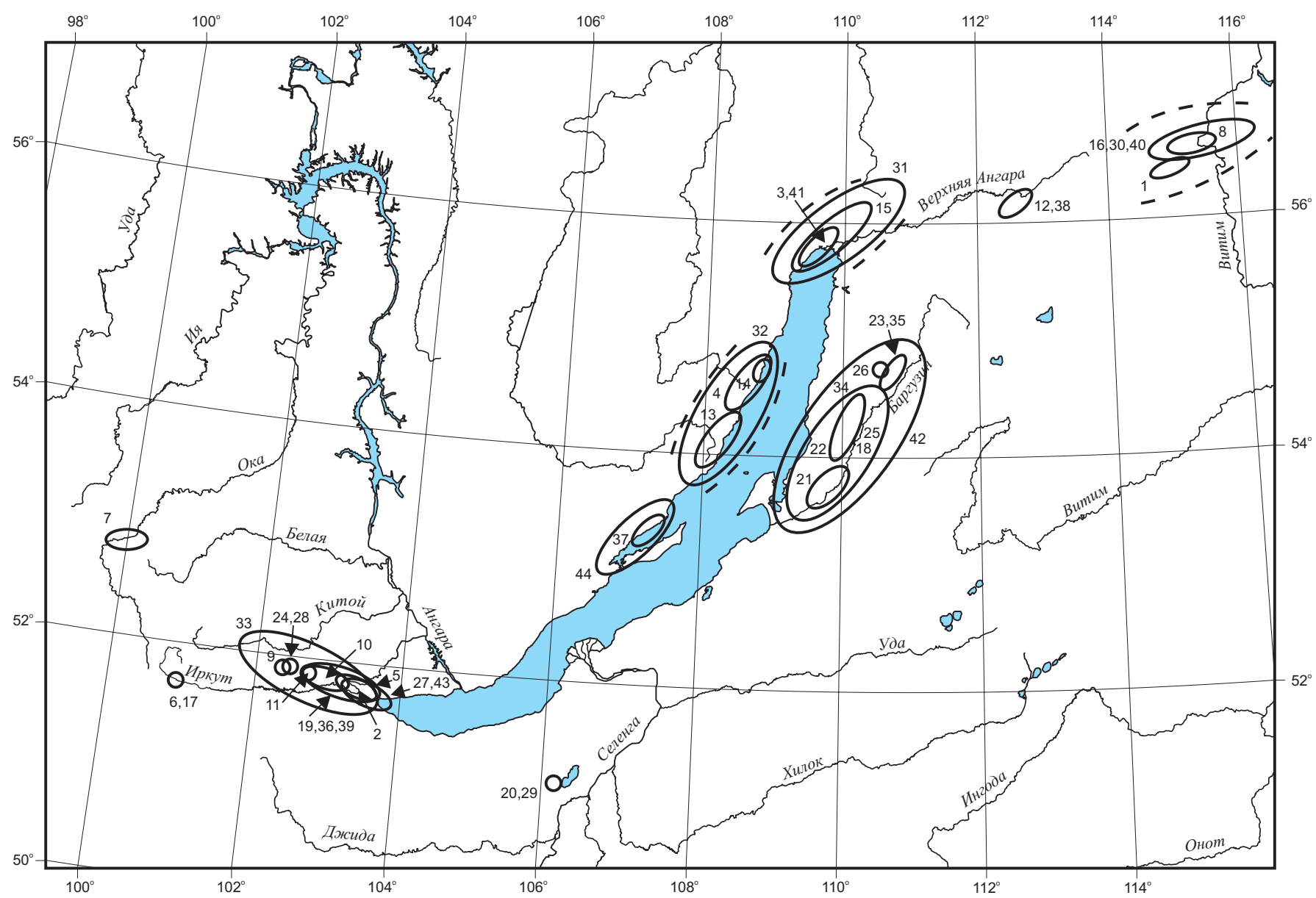

Рис. 7. Карта палеоземлетрясений Прибайкалья. Номера палеоземлетрясений приведены согласно табл. 3. Длинная ось эллипса соответствует протяженности вскрывшегося фрагмента разлома. Площадь эллипса оконтуривает район возможного проявления вторичных сейсмогенных деформаций.

Fig. 7. Map of paleoearthquakes in the Pribaikalie. Numbers of paleoearthquakes are given according to Table 3 . The long axis of the ellipse corresponds to the length of the opened fault fragment. The ellipse's area contours the region where secondary seismogenic deformations may occur.

уступа. Параметр D можно установить даже у полностью уничтоженной и не выраженной в рельефе сейсмодислокации. Резкие и значительные изменения $D$ не препятствуют определению $M$, так как у менее сильных землетрясений они варьируются от нескольких сантиметров до десятков сантиметров, а у сильных и сильнейших - от нескольких метров до 10-15 м. Главное заключается в том, чтобы пользоваться однотипными (максимальными или средними) значениями амплитуд. Для определения $M$ палеоземлетрясений использование максимальных амплитуд более приемлемо, так как именно их мы находим в сохранившихся фрагментах и они же позволяют найти остатки палеосейсмодислокаций. В отрезках палеосейсмодислокаций, утративших морфологическую выраженность, и были минимальные D.

По данным ряда исследователей [Никонов, 1977; Bonilla et al., 1984], для современных сейсмодислокаций соотношение вида $M=f(D)$ не менее надежно, чем $M=f(L)$, а соотношение типа $M=f(L D)$, по [Bonilla et al., 1984], характеризуется наиболее высоким ко- эфффициентом корреляции. Что же касается палеосейсмодислокации, представленной отдельными фрагментами, то ее сохранившаяся общая длина определенно и значительно меньше возникшей при палеоземлетрясении. Поэтому параметр D должен отражать величину палеоземлетрясения намного ближе к истинной, поскольку в сохранившихся фрагментах палеосейсмодислокации его можно установить. По данным А.Л. Строма и А.А. Никонова [Стром, Никонов, 1998], протяженность части современных сейсмодислокаций с $D_{\max }$ составляет в среднем менее $5 \%$ всей ее длины. Из этого очевидна ущербность оценки $M$ палеоземлетрясений по L связанных с ними палеосейсмодислокаций. Судя по каталогу землетрясений Северной Евразии и накопленной статистике палеособытий, большинство палеосейсмодислокаций Прибайкалья образовалось при палеоземлетрясениях с $M$ в пределах 6.0-6.5 и 7.0. Однако в Монголо-Байкальском регионе достоверные сейсмотектонические дислокации при таких землетрясениях, как правило, не образовывались (при Мондинском 9-балльном земле- 
Т а б л и ц а 3. Список палеоземлетрясений Прибайкалья

$\mathrm{T}$ a b l e 3. List of paleoearthquakes in the Baikal Region

\begin{tabular}{|c|c|c|c|c|c|c|c|c|}
\hline \multirow[t]{2}{*}{ № $\Pi / \Pi$} & \multirow{2}{*}{$\begin{array}{c}\text { Возраст события, лет } \\
\text { (крутизна уступов в градусах) }\end{array}$} & \multirow{2}{*}{\multicolumn{2}{|c|}{$\begin{array}{c}\text { Координаты центра } \\
\text { широта долгота }\end{array}$}} & \multicolumn{3}{|c|}{ Амплитуда смещения (D) в м } & \multirow{2}{*}{$\begin{array}{c}\text { Длина }(L) \\
\text { в км }\end{array}$} & \multirow{2}{*}{$\begin{array}{l}\text { Магнитуда } \\
\text { (M) }\end{array}$} \\
\hline & & & & вертикальн. & гор. & интеграл. & & \\
\hline 1 & 2 & \multicolumn{2}{|r|}{3} & 4 & 5 & 6 & 7 & 8 \\
\hline 1 & 1725 г.? & 56.42 & 114.97 & 6 & - & - & 15 & $7.4-7.9$ \\
\hline 2 & 1742 г.? <438; 40 & 51.75 & 103.55 & 0.5 & 1 & 1.1 & 40 & 7.1 \\
\hline 3 & $38-40^{\circ}$ & 55.77 & 109.57 & 6.5 & - & - & $>30$ & 7.6 \\
\hline 4 & $38-43^{\circ}$ & 54.47 & 108.57 & 6.5 & - & - & 75 & 7.9 \\
\hline 6 & 497-654 & 51.68 & 100.95 & $?$ & - & - & $?$ & - \\
\hline 7 & $679-797$ & 52.80 & 100.00 & 1.5 & 2 & 2.3 & 24 & 7.4 \\
\hline 8 & $37^{\circ}$ & 56.62 & 115.32 & 5 & - & - & 21 & 7.4 \\
\hline 9 & $1315-1742 ; 44^{\circ}$ & 51.90 & 102.37 & 0.9 & 1.8 & 2.0 & 10 & 7.3 \\
\hline 10 & $1406-2056 ; 30^{\circ}$ & 51.80 & 103.40 & 5 & 8 & 8.6 & 46 & 8.0 \\
\hline 11 & 2464-2809 & 51.85 & 102.97 & 0.7 & 2.1 & 2.2 & 23 & 7.4 \\
\hline 12 & $34^{\circ}$ & 56.17 & 112.59 & 4 & - & - & 13 & 7.3 \\
\hline 13 & $31-36^{\circ}$ & 54.17 & 108.37 & 6 & - & - & 70 & 7.8 \\
\hline 15 & $32-35^{\circ}$ & 55.97 & 109.98 & 6.5 & - & - & 60 & 7.8 \\
\hline 16 & $30-33^{\circ}$ & 56.60 & 115.40 & 7.5 & - & - & $>21$ & 8.0 \\
\hline 17 & $<3360$ & 51.68 & 100.95 & $?$ & - & - & $?$ & - \\
\hline 18 & $3574-3730$ & 54.17 & 110.14 & $?$ & - & - & $?$ & $(7.0)$ \\
\hline 19 & $3271-4435$ & 51.87 & 103.87 & $3-4$ & $7-8$ & 8.3 & 60 & 8.0 \\
\hline 20 & $<4299 ; 31^{\circ}$ & 51.13 & 106.18 & 2 & - & - & $2-3$ & 7.3 \\
\hline 21 & $3990-4840 ; 32-36^{\circ}$ & 53.75 & 109.13 & 6.5 & - & - & 45 & 7.7 \\
\hline 22 & $3990-4840 ; 32-36^{\circ}$ & 54.17 & 109.81 & 6.5 & - & - & 58 & 7.8 \\
\hline 23 & $3990-4840 ; 32-36^{\circ}$ & 54.61 & 110.58 & 6.5 & - & - & 33 & 7.6 \\
\hline 24 & $5257-5907$ & 51.92 & 102.47 & 0.45 & 1.35 & 1.5 & 34 & 7.2 \\
\hline 25 & $30^{\circ}$ & 54.10 & 110.10 & 5.5 & - & - & $?$ & 7.5 \\
\hline 26 & $30^{\circ}$ & 54.80 & 110.53 & 7 & - & - & 20 & 7.6 \\
\hline 27 & $6482-7681$ & 51.87 & 103.87 & $3-4$ & $7-8$ & 8.3 & 95 & 8.0 \\
\hline 28 & 7091-7385 & 51.92 & 102.47 & 0.9 & 1.8 & 2.0 & 10 & 7.3 \\
\hline 29 & $>7668 ; 22-27^{\circ}$ & 51.13 & 106.18 & 4.5 & - & - & $2-3$ & 7.5 \\
\hline 30 & $24-30^{\circ}$ & 56.60 & 115.40 & $10-20$ & - & - & $>21$ & \\
\hline 31 & $\left(30^{\circ}\right)$ & 55.87 & 109.77 & $20-30$ & - & - & 95 & 10 \\
\hline 34 & $9116-9305 ; 24^{\circ}$ & 54.83 & 110.58 & 6.5 & - & - & 124 & 8.1 \\
\hline 35 & $9116-9305 ; 24^{\circ}$ & 54.61 & 110.08 & 6.5 & - & - & 33 & 7.6 \\
\hline 36 & $8720-10074$ & 51.88 & 102.73 & 4.1 & 7.1 & 8.1 & 70 & 8.0 \\
\hline 37 & $20-24^{\circ}$ & 53.33 & 107.28 & 5 & - & - & 25 & 7.5 \\
\hline 38 & $22^{\circ}$ & 56.17 & 112.59 & - & - & - & 13 & 7.3 \\
\hline 39 & $10386-11187$ & 51.88 & 102.73 & 4.1 & 7.1 & 8.1 & 70 & 8.0 \\
\hline 40 & $20^{\circ}$ & 56.60 & 115.40 & $3-4$ & - & - & $?$ & - \\
\hline 41 & $20-22^{\circ}$ & 55.87 & 109.77 & 6.5 & - & - & $?$ & 7.6 \\
\hline 42 & $20^{\circ}$ & 54.61 & 110.31 & 9.5 & - & - & 180 & 8.2 \\
\hline 43 & $12095-13049$ & $(51.87$ & $103.87)$ & $?$ & - & - & $?$ & - \\
\hline 44 & $15-19^{\circ}$ & 53.27 & 107.10 & 5 & - & - & 95 & 7.9 \\
\hline
\end{tabular}

П р и м е ч а н и е. В пятом столбце буквами Л и П обозначены направления горизонтальной составляющей подвижки, соответственно левая и правая, прочерками отмечены дислокации, для которых горизонтальные перемещения не установлены.

$\mathrm{N}$ o t e. In column 5 , letters $\Omega$ and $\Pi$ refer to horizontal sinistral and dextral displacement, accordingly; boxes of dislocations with no horizontal movements identified are marked with dashes.

трясении в 1950 г. с $M=7$ возникла система приповерхностных трещин в рыхлых отложениях террас р. Иркут общей протяженностью 2.5 км и с амплитудами вертикальных смещений, не превышающими 0.3-0.8 м [Сейсмогеология..., 1981]). Поэтому в условиях Прибайкалья палеосейсмодислокации были связаны с палеоземлетрясениями, М которых была равна 7.0 или превышала это значение [Чипизубов, 1998], а в большинстве случаев в реальности обнаруживаются дислокации, связанные с более сильными $(M \geq 7.5)$ палеоземлетрясениями.

Поскольку в Прибайкалье поверхностное разрывообразование начинает проявляться при землетрясениях с $M \geq 7.0$, наиболее достоверные магниту- ды палеособытий можно получить из соответствующих соотношений с учетом стандартной ошибки. Подтверждением этому может служить тот факт, что при Муйском землетрясении 1957 г. $\left(M_{S}=7.6\right.$; $\left.M_{B}=7.5 ; M_{R}=7.8\right)$ интегральная амплитуда смещения не превышала 3.6 м, а протяженность разрыва составляла только 30 км. Такие параметры сейсморазрыва по соотношениям для сдвигов соответствуют землетрясению с $M D=7.3$ и $M L=6.9$. Подобный прием можно применять для определения магнитуд палеособытий со сбросовым, взбросовым и сдвиговым разрывообразованием. При определении магнитуд палеоземлетрясений в Прибайкалье, сопровождавшихся разрывообразованием взбросо-сдви- 
Ю

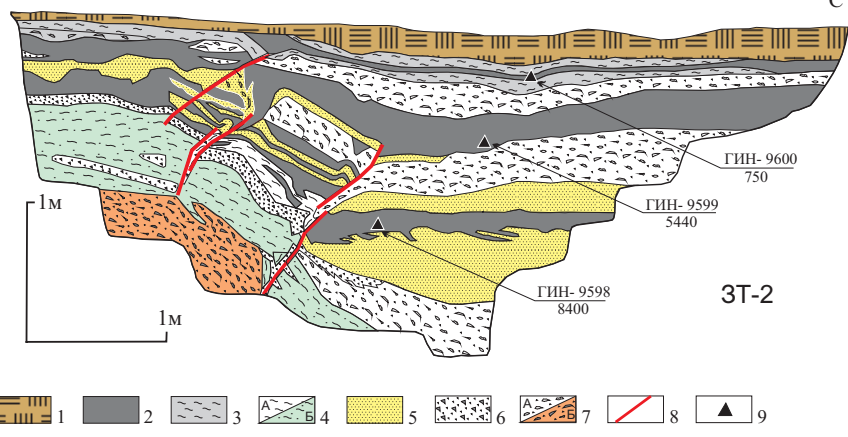

Рис. 8. Разрез стенки канавы ЗТ-2, Торская палеосейсмодислокация.

1 - современный почвенно-растительный покров; 2 - погребенные почвы; 3 - слабо гумусированные суглинки; 4-6 - составные части делювиально-пролювиальных отложений: 4 - суглинок (А) и суглинок с дресвой (Б), 5 - супесь, песок, 6 - щебень; 7 - рыхлый (А) и уплотненный (Б) галечник; 8 - разрывные нарушения; 9 - места отбора проб на радиоуглеродный анализ.

Fig. 8. Cross-section of the wall of Trench 3T-2 in the Torskaya paleoseismic dislocation.

1 - recent soil cover; 2 - buried soil; 3 - low-humous clayey soil; 4-6 - components of deluvial and proluvial deposits: 4 - clayey soil (A) and clayey soil with debris (Б), 5 - sand loam and sand, 6 - crushed stone; 7 - loose (A) and consolidated (E) gravel; 8 - loose (A) and consolidated (Б) crushed blocky deluvium; 9 - fractures; 10 - sampling points for radiocarbon studies.

гового типа, можно использовать регрессионные соотношения, полученные для активизированных платформ [Чипизубов, 1998].

$$
\begin{array}{ll}
M_{L}=1.07 \log L+5.65 & s=0.11, n=11, r=0.95 \\
M_{D}=1.10 \log D+7.0 & s=0.23, n=11, r=0.84
\end{array}
$$

где $r$ - коэфффициент парной корреляции, s - стандартная ошибка определения зависимой переменной, $\mathrm{n}$ - число коррелируемых пар.

Для определения $M$ палеособытий с неустановленным типом разрывообразования использовалось соотношение для разрывов всех типов с $D_{\max }>3$ [Стром, 1993]:

\section{$M=0.689 L N D+6.35 ; \quad R^{2}=0.489$.}

К настоящему времени в Прибайкалье установлено более 40 палеоземлетрясений с $M=7.1-8.0$, из которых только 24 датировано по ${ }^{14} \mathrm{C}$ (всего отобрано и датировано более 140 проб). В табл. 3 приведен список датированных на настоящее время палеоземлетрясений Прибайкалья. Такие палеособытия выделены в зонах Окино-Жомболокского, Баргузинского, Главного Саянского, Тункинского, Парамского, Приморского, Северо-Байкальского, Уколкитского и Хамбинского разломов (рис. 6).

\section{ЗАКЛЮЧЕНИЕ}

Палеосейсмологическими исследованиями установлены палеособытия с амплитудами смещения от 2-3 до 6-7 м. Мощные и пока не расчлененные (в
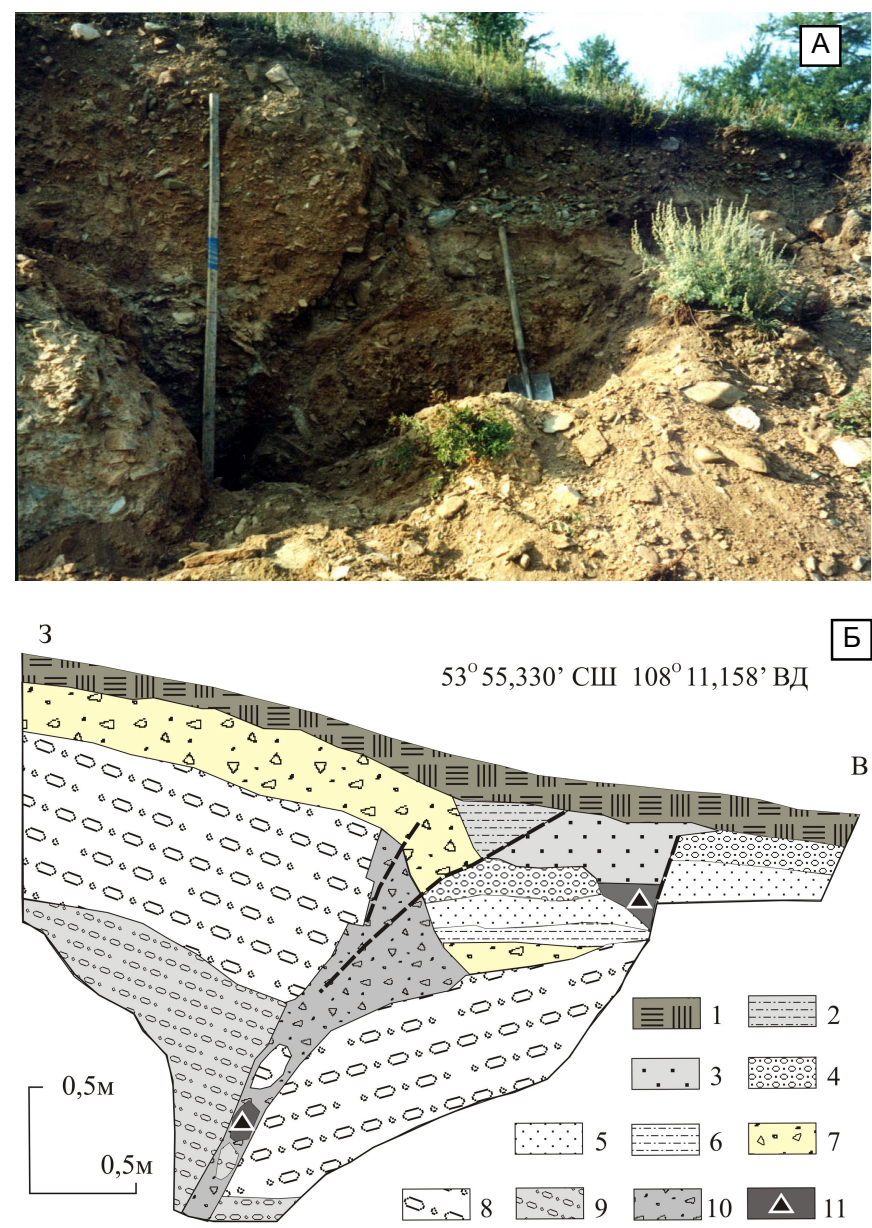

Рис. 9. Зачистка взбросового уступа в левом борту конуса выноса р. Шартлай в зоне Северо-Байкальского разлома (фото, А) и схема разреза зачистки (Б).

1 - современный почвенно-растительный покров; 2 - дресвяносуглинистые образования; 3 - дресвяно-щебенистые образования; 4-6 - байкальские стратифицированные галечниковые (4), супесчаные (5) и суглинистые (6) отложения; 7-9 - делювиальнопролювиальные отложения белесого (7), коричневатого (8), синевато-серого (9) цветов; 10 - смесь из отложений 8, 9 и гумусированных образований с большим количеством древесных углей; 11 - погребенные гумусированные образования и пробы на радиоуглеродный анализ. Жирный пунктир предполагаемые разрывные трещины.

Fig. 9. Cross-section of the stripping site wherein a thrust fault plane was discovered in the alluvial cone of the Shartlai River. The NorthBaikal fault.

1 - recent soil cover; 2 - debris-clayey deposits; 3 - debris-loamy clay deposits; 4-6 - baikalian stratified pebble (4), sandy loam (5) and clayey (6) sediments; 7-9 - whitish (7), brownish (8), and bluegrayish (9) deluvial and proluvial sediments; 10 - mixture of sediments 8,9 and humous deposits with abundant charcoal; 11 - buried humous deposit, and samples for radiocarbon studies. Thick dotted lines show possible fractures.

силу отсутствия тренчинговых работ на них), вероятно сейсмогенные уступы находятся в зонах Тункинского, Уколкитского, Северо-Байкальского, Кичерского и Баргузинского разломов. Симптоматично, что в зонах этих разломов, а также в зонах Приморского и Главного Саянского наиболее мощные палеоземлетрясения происходили 9-10 тыс. лет назад [Чипизубов и др., 2002]. 
Палеосейсмологические данные, помимо выявления сильнейших досейсмостатистических землетрясений с определением их возраста и магнитуд, дают прямые свидетельства и о возможных кинематических типах активизированных разломов. Так, в зонах Тункинского и Северо-Байкальского разломов выявлены палеосейсмодислокации взбрососдвигового и взбросового типов (рис. 7, 8, 9), необычные для структур Байкальской рифтовой зоны. Взбросо-сдвиговые смещения по зоне Тункинского разлома находят приемлемое объяснение с геодинамических позиций (субширотная ориентировка разлома и северо-восточное направление сжимающих напряжений) и не противоречат сейсмологическим данным о механизмах очагов землетрясений.

Несомненно, что прогресс в понимании причин и механизмов позднекайнозойского разломообразования Прибайкалья, сопровождавшегося мощными сейсмическими процессами, будет во многом зависеть от дальнейшего развития и сохранения традиций сибирской школы палеосейсмогеологии, возникшей в свое время как новаторский метод изучения сейсмогенных структур.

Работа выполнена при финансовой поддержке РФФИ (гранты 06-05-64492-а, 07-05-00760-а) и Сибирского отделения РАН (интеграционный проект СО РАН ИП-87).

\section{ЛИТЕРАТУРА}

Аржанникова А.В., Аржанников С.Г. Сейсмотектонические деформации в западной части Тункинских гольцов и современная экзодинамика // Геология и геофизика. - 1999. - Т. 40, № 2. - С. 231-234.

Геология и сейсмичность зоны БАМ. Сейсмогеология и сейсмическое районирование / В.П. Солоненко, В.В. Николаев, Р.М. Семенов и др. - Новосибирск: Наука, 1985. - 191 с.

Гоюй Д. Краткий обзор последних исследований в палеосейсмологии (перевод с китайского) // Шицянь дичжень юй дисыцзы дичжи вэньцзи. Сб. ст. 1982. - С. 3-7.

Дельянский E.A. Следы сейсмогенных деформаций в рыхлых отложениях плейстосейстовой зоны Цаганского землетрясения // Геология и полезные ископаемые Восточной Сибири: Тезисы докладов научной конференции. - Иркутск: ИГУ, 1993. - С. 7-8.

Дельянский Е.А., Макаров С.А., Белоусов О.В. Сейсмичность Приморского разлома по результатам тренчинга // Геология и геофизика Восточной Сибири: Тезисы докладов. - Иркутск: ИГУ, 1992. - С. 16-17.

Дельянский Е.А., Хромовских В.С. Циклическое развитие сейсмогенных структур в зоне разлома Черского (Южное Прибайкалье) // Всероссийское совещание по изучению четвертичного периода. - М., 1994. - С. 79.

Дислокации Гоби-Алтайского (Монголия) землетрясения 1957 г. / П. Молнар, Р.А. Курушин, А. Баясгалан, К.В. Хаднат. - Новосибирск: Изд-во СО РАН, 1998. - 148 с.

Живая тектоника, вулканы и сейсмичность Станового нагорья / В.П. Солоненко, А.А. Тресков, Р.А. Курушин и др. - М.: Наука, 1966. $-231 \mathrm{c}$

Корженков А.М., Мазор Э. Структурная реконструкция сейсмических событий: руины древних городов как окаменевшие сейсмографы // Известия МОН РК, НАН РК. - 2001. - № 1. C. $108-125$.

Ласточкин С.B. Определение возраста палеосейсмогенных структур по морфометрическим показателям // Геология и геофизика. - 1981. - № 1. - С. 91-94.

Ласточкин C.B. К сейсмогеологии Западного и Центрального Забайкалья // Поздний плейстоцен и голоцен юга Восточной Сибири. К XI Конгрессу INQUA в СССР, Москва, 1982. - Новосибирск: Наука, 1982. - С. 136-145.

Лунина О.В. Влияние напряженного состояния литосферы на соотношения параметров сейсмогенных разрывов и магнитуд землетрясений // Геология и геофизика. - 2001. - Т. 42, № 9. - С. 1389-1398.

Никонов А.А. Голоценовые и современные движения земной коры. - М.: Наука, 1977. - 240 с.

Никонов А.А. Датирование сейсмотектонических подвижек и древних землетрясений с помощью радиоуглеродного анализа и археологических данных (на примере гор Средней Азии) // Доклады АН СССР. - 1981. - Т. 257, № 2. - С. 440444.

Новый каталог сильных землетрясений на территории СССР с древнейших времен до 1975 г. / Отв. ред. Н.В. Шебалин, Н.В. Кондорская - М.: Наука, 1977. - 535 с.

Ружич В.В., Леви К.Г., Дельянский Е.А., Смекалин О.П. Оценки повторяемости сильных землетрясений Прибайкалья по материалам сейсмогеологических исследований // Геологическая среда и сейсмический процесс: Материалы Всероссийской межрегиональной конференции. - Иркутск: ИЗК СО РAH, 1997. - C. 144-147.

Ружич В.В., Саньков В.А., Днепровский Ю.И. Дендрохронологическое датирование сейсмогенных разрывов в Становом нагорье // Геология и геофизика. - 1982. - № 8. - С. 122-126.

Сейсмическое районирование Восточной Сибири и его геологогеофизические основы. - Новосибирск: Наука, 1977. - 304 с.

Сейсмогеология и детальное сейсмическое районирование Прибайкалья / Под ред. В.П. Солоненко. - Новосибирск: Наука, 1981. - 169 с

Сейсмотектоника и сейсмичность рифтовой системы Прибайкалья / Под ред. В.П. Солоненко. - М.: Наука, 1968. - 220 с.

Сейсмотектоника и сейсмичность юго-восточной части Восточного Саяна / Под ред. В.П. Солоненко. - Новосибирск: Наука, 1975. - 134 c.

Смекалин О.П., Имаев В.С., Чипизубов А.В., Семёнов Р.М. Изучение сейсмогенных сбросов Кичерской структуры в разрезах канав // Тихоокеанская геология. - 2007. - Т. 26, № 2. - С. 82-92.

Солоненко В.П. Определение эпицентральных зон землетрясений по геологическим признакам // Известия АН СССР. Серия геологическая. - 1962. - № 11. - С. 58-74.

Солоненко В.П. Сейсмогенные деформации и палеосейсмогеологический метод // Сейсмическое районирование Восточной Сибири и его геолого-геофизические основы. - Новосибирск: Наука, 1977. - С. 5-47.

Стром А.Л. Оценка амплитуд сейсмогенных подвижек по тектоническим нарушениям В основаниях гидротехнических сооружений // Гидротехническое строительство. - 1993. - № 3. - С. 13-17.

Стром А.Л. Количественные характеристики сейсмогенных разрывов и их использование в палеосейсмогеологии и инженерной геологии: Автореф. дис. ... канд. геол.-мин. наук. - М.: Гидропроект, 1998. - $26 \mathrm{c}$.

Стром А.Л., Никонов А.А. Распределение смещений вдоль сейсмогенных разрывов и учет неравномерности подвижек при палеосейсмологических исследованиях // Современная сейсмология: Достижения и проблемы: Тезисы научной конференции. - М., 1998. - С. 23-24.

Трифонов В.Г., Караханян А.С. Геодинамика и история цивилизаций. - М.: Наука, 2004. - 668 с.

Флоренсов Н.A. Неотектоника Прибайкалья в связи с его сейсмичностью // Бюллетень совета по сейсмологии. № 10 (Вопросы сейсмотектоники Прибайкалья и смежных территорий). - М.: Изд-во АН СССР, 1960. - С. 11-20.

Хромовских В.С. Главные признаки и способы выявления сейсмодеформаций // Современная динамика литосферы континентов. Методы изучения. - М.: Недра, 1989. - С. 229-235.

Хромовских В.С. Использование палеосейсмогеологических данных при составлении карты очаговых зон землетрясений (на примере Байкальской рифтовой системы) // Сейсмичность и сейсмическое районирование Северной Евразии. Вып. 2-3. М.: ОИФЗ РАН, 1995. - С. 300-307.

Хромовских В.С., Дельянский Е.А., Смекалин О.П. Палеосейсмогеология на новом этапе развития // Геофизические исследования в Восточной Сибири на рубеже XXI века. - Новосибирск: Наука, 1996. - С. 99-101.

Хромовских В.С., Солоненко В.П., Чипизубов А.В., Жилкин В.М. К сейсмотектонической характеристике Северного Прибайкалья // Сейсмичность и глубинное строение Прибайкалья. Новосибирск: Наука, 1978. - С. 101-107.

Хромовских В.С., Чипизубов А.В., Курушин Р.А., Смекалин О.П., 
Дельянский E.A. Новые данные о палеосейсмодислокациях Байкальской рифтовой зоны // Сейсмичность и сейсмическое районирование Северной Евразии. Вып. 1. - М.: Наука, 1993. - C. 256-264.

Чипизубов A.B. Сейсмогеология Северного Прибайкалья (зона БАМ): Автореф. дис. ... канд. геол.-мин. наук. - Иркутск: ИЗК CO PAH, 1982. - $17 \mathrm{c}$

Чипизубов А.В. Выделение одноактных и одновозрастных палеосейсмодислокаций и определение по их масштабам магнитуд палеоземлетрясений // Геология и геофизика. - 1998. - № 3. - C. 386-398

Чипизубов А.В., Аржанников С.Г., Семёнов Р.М., Смекалин О.П. Палеоземлетрясения и палеосейсмодислокации в зоне Баргузинского разлома // Геология и геофизика. - 2007. - Т. 48 № 7. - С. 753-766.

Чипизубов А.В., Аржанников С.Г., Семёнов Р.М., Смекалин О.П. Серебренников С.П. Палеосейсмодислокации и палеоземлетрясения Прибайкалья // Геология, геохимия и геофизика: Материалы Всероссийской научной конференции, посвящённой 10-летию Российского фонда фундаментальных исследований. - Иркутск: ИЗК СО РАН, 2002. - С. 535-537.

Чипизубов А.В., Семенов Р.М., Аржанников С.Г., Смекалин О.П. Новые данные о палеосейсмодислокациях в зоне Баргузинского разлома (Байкальская рифтовая система) // Доклады АН. - 2000. - T. 372, № 3. - С. 393-396.

Чипизубов А.В., Серебренников С.П. Сдвиговые палеосейсмодислокации в Восточном Саяне // Доклады АН СССР. - 1990. - T. 311, № 2. - С. 446-450

Чипизубов А.В., Смекалин О.П. Периодичность сейсмогенного вскрытия Главного Саянского разлома по палеосейсмогеологическим данным // Всеросийское совещание по изучению четвертичного периода: Тезисы докладов. - М., 1994. - С 254

Чипизубов А.В., Смекалин О.П. Палеосейсмодислокации и связанные с ними палеоземлетрясения по зоне Главного Саянского разлома // Геология и геофизика. - 1999. - Т. 40, № 6. C. 936-947.

Чипизубов А.В., Смекалин О.П., Белоусов О.В., Дельянский Е.А., Щеголев Ю.В. Взбросо-сдвиговые палеосейсмодислокации по зоне Главного Саянского разлома // Доклады АН. - 1994. Т. 338, № 5. - С. 672-674.

Ян Ц., Го Ч., Цао Ц. Исследование голоценовой активности передового разлома хребта Хэланьшань с использованием геоморфологических методов // Дичжэнь дичжи (Seismology and Geology). - 1985. - Т. 7, № 4. - С. 23-31 (перевод с китайского).

Andrews D.J., Hanks T.C. Scarp degraded by linear diffusion - Inverse solution for age // Journal of Geophysical Research. 1985. - V. 90, № B12. - P. 10193-10208.

Bonilla M.G., Mark R.K., Lienkaemper J.J. Statistical relations among earthquake magnitude, surface rapture length, and surface fault displacement // Bulletin of Seismological Society of America. 1984. - V. 74, № 6. - P. 2379-2411.

Brogan G.E., Kellog K.S., Slemmons B., Terhune C.L. Late Quaternary faulting along the Death Valley - Furnace Creek fault system, California and Nevada // US Geological Survey Bulletin. 1991. - № 1991. - P. 1-23.

Bucknam R.C., Anderson R.E. Estimation of fault scarp ages from a scarp height-slope angle relationship // Geology. - 1979. - V. 7 № 1. - P. 11-14.

Clark M.M., Grantz A., Rubin M. Holocene activity of the Coyote Creek fault as recorded in sediments of Lake Cahuilla // The Borrego Mountain earthquake of April 9, 1968. - U.S. Geological Survey Professional Paper 787. - 1972. - P. 112-130.

Colman S.M., Pierce K.L., Birkeland P.W. Suggested terminology for Quaternary dating methods // Quaternary Research. - 1987. - V. 28. - P. 314-319.

Colman S.M., Watson K. Ages estimated from a diffusion equation model for scarp degradation // Science. - 1983. - V. 221. - P 263-265.

Deng Q., Liao Y. Paleoseismology along the range-front fault of $\mathrm{He}$ Ian Mountains, North Central China // Journal of Geophysical Research. - 1996. - V. 101, № B3. - P. 5873-5893.

Forman S.L., Jackson M.E., McCalpin J., Maat P. The potential of using thermoluminescence to date buried soils in colluvial and fluvial sediments from Utah and Colorado, U.S.A. // Quaternary Science Reviews. - 1988. - V. 7, № 3-4 - -287-293.
Gilbert G.K. Report on the geology of portions of Nevada, Utah, California, and Arizona examined in the years 1871 and 1872 // Report on U.S. Geographical and Geological Surveys West of the 100th Meridian - 1875 - № 3 - Pt 1 - P 17-187.

Gilbert G.K. Lake Bonneville // U.S. Geological Survey. 1890. Monograph 1. $-438 \mathrm{p}$.

Hanks T.C., Andrews D.J. Effect of far-field slope on morphologic dating of scarplike landforms // Journal of Geophysical Research. - 1989. - V. 94, № B1 - P. 565-573.

Hatheway A.W., Leighton F.B. Trenching as an exploratory method / Eds. A.W. Hatheway, C.R. McClure Jr. // Geology in the Siting of Nuclear Power Plants. Geol. Soc. Am. Rev. Eng. Geol. - 1979. IV. - P. 169-196.

Hull A.G. Paleoseismic slip at reverse faults // U. S. Geol. Survey. 1987. Open-File Report, 87-673. - P. 262-270.

Lund W.R. Introduction to paleoseismology of Utah // Paleoseismology of Utah. - 1991. V. 1. Utah Geological and Mineral Survey. Special studies. 75. P. 1-9.

Machette M.N. Quaternary and Pliocene faults in the La Jencia and southern part of the Albuquerque-Belen basins, New Mexico // Evidence of fault history from fault-scarp morphology and Quaternary geology. N. M. Geol. Soc. 1982. 33rd Field Conf. Guidebook. Albuquerque Country II. - P. 161-169.

Machette M.N. Changes in longterm versus short-term slip rates in an extensional environment. U.S. Geol. Survey. 1987. Open-File Report, 87-673. - P. 228-238.

Mayer L. Dating quaternary fault scarps formed in alluvium using morphologie parameters // Quaternary Research. - 1984. - V. 22. - P. 300-313.

McCalpin J.P. Current investigative techniques and interpretive models for trenching active dip-slip faults // Engineering Geology and Geotecnical Engineering. - Balkema, Rotterdam, 1989. - P. 249258

McCalpin J.P., Forman S.L. Chronology of paleoearthquakes on the Wasatch fault zone by thermolluminescence (TL) dating // U.S Geol. Survey. 1988. Open-File Report, 88-434. - P. 506-511.

McCalpin J.P., Khromovskikh V.S. Holocene paleoseismicity of the Tunka fault, Baikal rift, Russia // Tectonics. - 1995. - V. 14, № 3 - P. 594-605.

Nash D.B. Morphological dating of degraded normal fault scarps // Journal of Geology. - 1980. - V. 88. - P. 353-360.

Paleoseismology / Edited by J.P. McCalpin - San Diego: Academic press, 1996. $-585 \mathrm{p}$

Sanders C.O. Slemmons D.B. Geomorphic evidence for holocene earthquakes in the Olinghouse fault zone, Western Nevada // Bulletin of Seismological Society of America. - 1996. - V. 86, № 6. - P 1784-1792.

Sieh K.E. Prehistoric large earthquakes produced by slip on the San Andreas fault at Pallet Creek, California // Journal of Geophysical Research. - 1978. - V. 83, № B8. - P. 3907-3939.

Sieh K.E. A review of geological evidence for recurrence times of large earthquakes // Am. Geophys. Union. 1981. Maurice Ewing. Ser. 4

Sims J.D. Earthquake-induced structures in sediments of Van Norman Lake, San Fernando, California // Science. - 1973. - V. 182 - P. 161-163.

Sims J.D. Determining earthquakes recurrence intervals from deformation structures in young lacustrine sediments // Tectonophysics. - 1975. - V. 29. - P. 141-152.

Vittori E., Labini S.S., Serva L. Palaeoseismology: review of the state-of-the-art // Tectonophysics. - 1991. - V.193, № 1-3. - P 9-32.

Wallace R. E. Profils and ages of young fault scarp, North-Central Nevada // Geological Society of America Bulletin. - 1977. - V 88. - P. 1267-1281.

Wallace R.E. Degradation of the Hebgen Lake fault scarps of 1959 // Geology. - 1980. - V. 8. - P. 225-229.

Wallace R.E. A perspective of paleoseismology // Direction in paleoseismology. 1987. Open file report, 87-673. - Denver, Colorado. - P. 7-16.

Wells D.L., Coppersmith K.J. New empirical relationships among magnitude, rapture length, rapture width, rapture area and surface displacement // Bulletin of Seismological Society of America. - 1994. - V. 84, № 4. - P. 974-1002.

Yeats R.S., Sieh K., Allen C.R. The geology of earthquakes. - Oxford: Oxford University Press, 1997. - 568 p. 

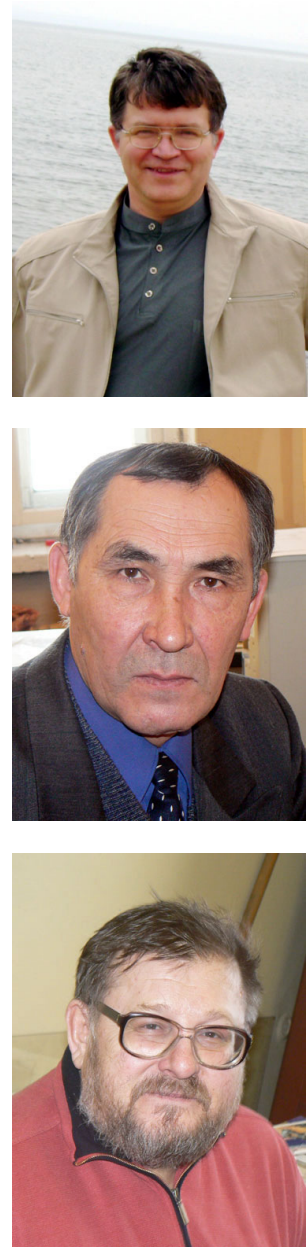

Смекалин Олег Петрович, канд. геол.-мин. наук, с.н.с.

Институт земной коры СО РАН, 664033, Иркутск, ул. Лермонтова, 128

e-mail: smekalin@crust.irk.ru

Smekalin, Oleg P., Candidate of Geology and Mineralogy, Senior Researcher 128 Lermontov street, Institute of the Earth's Crust, Irkutsk 664033, Russia e-mail: smekalin@crust.irk.ru

Чипизубов Анатолий Васильевич, докт. геол.-мин. наук, с.н.с.

Институт Земной коры СО РАН, 664033, Иркутск, ул. Лермонтова, 128

e-mail: chipizub@crust.irk.ru

Chipizubov, Anatoly V., Doctor of Geology and Mineralogy, Senior Researcher 128 Lermontov street, Institute of the Earth's Crust, Irkutsk 664033, Russia e-mail: chipizub@crust.irk.ru

Валерий Сулейманович Имаев, докт. геол.-мин. наук, зав. лабораторией Институт земной коры СО РАН, 664033, Иркутск, ул. Лермонтова, 128 e-mail: imaev@crust.irk.ru

Валерий Сулейманович Имаев, Doctor of Geology and Mineralogy, Head of Laboratory 128 Lermontov street, Institute of the Earth's Crust, Irkutsk 664033, Russia

e-mail: imaev@crust.irk.ru 